This material is presented to ensure timely dissemination of scholarly and technical work. Copyright and all rights therein are retained by authors or by other copyright holders. All persons copying this information are expected to adhere to the terms and constraints invoked by each author's copyright. In most cases, these works may not be reposted without the explicit permission of the copyright holder.

This version of the referenced work is the post-print version of the article-it is NOT the final published version nor the corrected proofs. If you would like to receive the final published version please send a request to any of the authors and we will be happy to send you the latest version. Moreover, you can contact the publisher's website and order the final version there, as well.

The current reference for this work is as follows:

Xiling “Celine” Cui, Vincent Siu-king Lai, and Paul Benjamin Lowry (2016). "How do bidders' organism reactions mediate auction stimuli and bidders' eloyalty in online auctions? The case of Taobao in China," Information \& Management (I\&M) (accepted 31-Jan-2016).

If you have any questions, would like a copy of the final version of the article, or would like copies of other articles we've published, please email any of us directly, as follows: cuixiling@gmail.com (for Celine), vslai@cuhk.edu.hk (for Vincent) and Paul.Lowry.PhD@gmail.com (for Paul).

Paul also has an online system that you can use to request any of his published or forthcoming articles. To go to this system, click on the following link: https://seanacademic.qualtrics.com/SE/?SID=SV_7WCaP0V7FA0GWWx 


\title{
How do bidders' organism reactions mediate auction stimuli and bidder loyalty in online auctions? The case of Taobao in China
}

\author{
Xiling Cui ${ }^{1}$, Vincent Siu-king Lai ${ }^{2}$, Paul Benjamin Lowry ${ }^{3}$ \\ 1: Department of Business Administration, Hong Kong Shue Yan University; \\ 2: Department of Decision Sciences and Managerial Economics, The Chinese University of Hong \\ Kong;
}

3: Department of Information Systems, City University of Hong Kong

\begin{abstract}
Nowadays, it is important for auction websites to obtain bidder loyalty. This study investigated the mediating effect of consumer perceptions between technological/brand stimuli and bidder loyalty to an online auction website by applying the traditional and evolutionary stimulus-organism-response models. We tested these models using 449 bidders from Taobao, an online auction service provider in China. Based on the results of covariance-based structural equation modelling, we showed that consumer perceptions fully mediate technological stimuli, but only partially mediate brand stimuli, and bidder loyalty. These results can be used to further improve the related research and practice.
\end{abstract}

\section{Keywords}

S-O-R model, evolutionary S-O-R model, bidder loyalty, online auctions, organism. 


\section{How do bidders' organism reactions mediate auction stimuli and bidder loyalty in online auctions? The case of Taobao in China}

\section{INTRODUCTION}

The last decade has witnessed a significant increase in online auction activity. This activity not only accounts for a large volume of the economic transactions conducted over the Internet but has also led to a revolution in the online and offline retail markets [1]. Moreover, the emergence of the Internet as a market force has helped minimize operating costs, lower entry barriers, and diminish physical travel, thus intensifying competition, which is now just a "click” away [2]. Hence, online auction service providers have made a practice of offering loyalty incentives and investing in customer retention programs in an effort to minimize their attrition rates and to maximize the repurchase intentions of their customers [3]. Online auction service providers use these retention investments to nurture bidder loyalty in their online communities. In today’s highly competitive online auction market, the ability to retain existing customers is fundamentally important, because retention is less costly and difficult than obtaining new customers and can help establish a sustainable competitive advantage [4].

Building customer loyalty requires critical resources and resource commitment, including developing an effective auction website that will encourage bidders’ participation. Hence, auction service operators must be able to refocus their digital resources toward developing a distinctive website to improve bidder loyalty. That is, an effective auction website may eventually stimulate the bidding motivation of customers, which in turn will sustain their loyalty to the website. However, the effect of a stimulating website is reflected by each customer's perceptions. Consequently, online auction service providers need to evaluate their customers' organism reactions to such website stimuli, before expecting customer loyalty as a response.

Accordingly, this study aims at applying traditional and evolutionary stimuli-organism-response (S-O-R) frameworks to investigate bidder loyalty in online auctions. According to the traditional S-O-R model, environmental stimuli can lead to cognitive and affective reactions that cause certain behaviour to 
be performed [5]. The model, which has been widely applied and successfully validated in information systems (IS) research, considers the organism to be the mediator between the stimulus and the response [6-9]. A recent meta-analysis of S-O-R research [10] has also confirmed the validity of the organism as a theoretical construct for empirical investigation. However, the results concerning the mediating role of the organism in the model have been mixed. For example, the emotional state of online shoppers has been shown to fully mediate the effect of design on shopping behaviour but to only partially mediate the ambience [11]. By contrast, Thang and Tan [12] identified a direct stimulus-response relationship between store image and consumer retail behaviour. These mixed results suggest that the full mediation of organism between stimulus and response suggested by the traditional S-O-R framework may varyparticularly when psychologically complex, dynamic, and recursive phenomena are being modelled [13]. The evolutionary S-O-R framework [13] with varied relationships between stimulus, organism and response, thus, may be a better fit.

Online auction websites can have different effectiveness measures in relation to factors such as technological service and branding. Thus, their psychological effects on bidders are likely to be heterogeneous and complex. Although the traditional S-O-R model offers insights into the full mediating effect of the organism, researchers have argued that the idea of a partial mediating effect has heuristic value for theory building because it can uncover other missing mediators and underlying relationships [14]. Accordingly, these researchers have stated that more attention should be paid to partial mediation. We respond to this call by investigating the full and partial mediating effects of bidders' organism reactions on the relationship between making an auction website more stimulating and bidder e-loyalty based on the traditional and evolutionary S-O-R frameworks.

Based on the above arguments, in this study we focus on the following research questions:

1) Which factors influence bidder loyalty to online auction websites?

2) Do different factors show the same patterns in terms of their effects?

3) Does the fully or the partially mediating S-O-R model better explain e-loyalty to online auction 
websites?

Although the antecedents of e-loyalty in online auction websites have been investigated in previous studies, most of the technological factors are some general website characteristics and few are specific to online auctions and the brand factors that also need to be investigated. The extant literature has also provided mixed research findings on the mediating effects of utilitarian and hedonic factors.

Therefore, this study selected bidders' perceived bidding utility and enjoyment as the organism reactions. The results of this study can contribute to the existing research and practice in several ways. First, our findings can provide insights for online auction service providers to determine whether to place greater emphasis on website branding or technology enhancement. Moreover, the validity confirmation of the evolutionary S-O-R, in relation to bidder loyalty can help to reconcile inconsistent S-O-R results. Finally, the discussion on the causal direction of cognitive and affective perceptions in online auction context echoes the need for this research gap [7].

\section{RESEARCH BACKGROUND}

\section{Studies on E-loyalty to Websites}

E-loyalty is defined as the "perceived intention to visit or use a website in the future and to consider purchasing from it in the future” [15]. A recent meta-analysis of the e-loyalty literature examined both the consequences and antecedents of e-loyalty [16]. In terms of consequences, the findings showed that e-loyalty, measured behaviourally or attitudinally, can increase cross-sales, customer profitability, willingness to pay more, and positive word-of-mouth (WOM) behaviour. Moreover, e-loyalty can reduce customer price sensitivity and alternative search behaviour. The results of the meta-analysis thus established the potentially positive and strategic effects of e-loyalty in online business environments.

In their meta-analysis, Toufaily et al. [16] also classified the antecedents of e-loyalty into five categories of characteristics relating to the website, product/service, company/retailer, customer, and environment. Upon further examination, we found that website characteristics mainly refer to the 
technological nature of the websites and that the product/service and company/retailer can be combined into one category, product or company. Therefore, we reviewed the antecedents of e-loyalty in relation to the following factors: technology, product or company, customer, and environment (as summarized in Table 1).

Table 1. Overview of Studies on E-loyalty

\begin{tabular}{|c|c|c|c|c|}
\hline Categories & Antecedents & Literature & Remarks & Summary \\
\hline \multirow{10}{*}{$\begin{array}{l}\text { Technological } \\
\text { factors }\end{array}$} & Website \& technology & {$[4]$} & $\begin{array}{l}\text { General } \\
\text { characteristics }\end{array}$ & \multirow{10}{*}{$\begin{array}{l}\text { Most studies deal } \\
\text { with general } \\
\text { characteristics; only } \\
\text { a few analyse } \\
\text { specific } \\
\text { technological } \\
\text { characteristics. }\end{array}$} \\
\hline & User interface & {$[17]$} & $\begin{array}{l}\text { General } \\
\text { characteristics }\end{array}$ & \\
\hline & eCRM system & {$[18]$} & $\begin{array}{l}\text { Specific } \\
\text { characteristics }\end{array}$ & \\
\hline & $\begin{array}{l}\text { Customization, } \\
\text { navigation, accuracy, } \\
\text { responsiveness, \& } \\
\text { assurance }\end{array}$ & [19] & $\begin{array}{l}\text { General } \\
\text { characteristics }\end{array}$ & \\
\hline & Perceived usability & {$[20]$} & $\begin{array}{l}\text { General } \\
\text { characteristics }\end{array}$ & \\
\hline & \multirow{2}{*}{$\begin{array}{l}\text { Navigation design, } \\
\text { visual design, \& } \\
\text { information design } \\
\text { Navigational quality }\end{array}$} & {$[15]$} & $\begin{array}{l}\text { General } \\
\text { characteristics }\end{array}$ & \\
\hline & & [21] & $\begin{array}{l}\text { General } \\
\text { characteristics }\end{array}$ & \\
\hline & \multirow{3}{*}{$\begin{array}{l}\text { Perceived usability \& } \\
\text { expertise } \\
\text { Recommendation } \\
\text { quality of the } \\
\text { recommendation agent } \\
\text { Technological design }\end{array}$} & {$[22]$} & $\begin{array}{l}\text { General } \\
\text { characteristics }\end{array}$ & \\
\hline & & [23] & $\begin{array}{l}\text { Specific } \\
\text { characteristics }\end{array}$ & \\
\hline & & [24] & $\begin{array}{l}\text { General } \\
\text { characteristics }\end{array}$ & \\
\hline \multirow{5}{*}{$\begin{array}{l}\text { Product or } \\
\text { company } \\
\text { factors }\end{array}$} & Lodging brand & {$[25]$} & Brand & \multirow{5}{*}{$\begin{array}{l}\text { Most studies focus } \\
\text { on reputation. There } \\
\text { is limited research on } \\
\text { branding. }\end{array}$} \\
\hline & Service quality & {$[26]$} & Service & \\
\hline & $\begin{array}{l}\text { Width of product } \\
\text { selection }\end{array}$ & [15] & Product & \\
\hline & Perceived capability & {$[21]$} & Capability & \\
\hline & Reputation & $\begin{array}{l}{[15 ; 21 ; 22 ;} \\
27]\end{array}$ & Reputation & \\
\hline \multirow[t]{2}{*}{$\begin{array}{l}\text { Customer } \\
\text { factors }\end{array}$} & $\begin{array}{l}\text { Trust as an } \\
\text { intermediary variable } \\
\text { between other } \\
\text { antecedents and } \\
\text { e-loyalty or repurchase } \\
\text { intention }\end{array}$ & $\begin{array}{l}{[15 ; 20 ; 21 ;} \\
27-30]\end{array}$ & $\begin{array}{l}\text { Most of the studies } \\
\text { confirm the mediating } \\
\text { effect. }\end{array}$ & \multirow[t]{2}{*}{$\begin{array}{l}\text { The studies mostly } \\
\text { focus on trust and } \\
\text { satisfaction, with } \\
\text { limited attention paid } \\
\text { to cognitive-affective } \\
\text { states. }\end{array}$} \\
\hline & $\begin{array}{l}\text { Satisfaction as an } \\
\text { intermediary variable }\end{array}$ & $\begin{array}{l}{[15 ; 17 ; 19 ;} \\
20 ; 27 ; 29]\end{array}$ & $\begin{array}{l}\text { Most of the studies } \\
\text { confirm the mediating }\end{array}$ & \\
\hline
\end{tabular}


between other

effect.

antecedents and

e-loyalty or repurchase

intention

Effectiveness \&

[30]

efficiency as well as

enjoyment

\begin{tabular}{llll}
\hline & Previous relationship & {$[31]$} & \\
Environmental & Online experiential & {$[32]$} & Studies are \\
factors & value & & diversified. \\
& Fairness or justice & {$[29 ; 33]$} & \\
\hline
\end{tabular}

Our literature review clearly indicates that the antecedents of e-loyalty have been widely investigated. However, we believe that three areas require further investigation. First, most of the technological factors relating to websites are highly general and only two studies [i.e., 18; 23] have investigated factors that are specific to the functions of their websites. Salmen and Muir [18], for example, investigated the use of electronic customer care technologies to create customer e-loyalty in the context of Internet banking. By contrast, Yoon et al. [23] investigated the use of general collaborative-filtering and random recommendation agents to improve e-customer loyalty on online shopping. However, studies have seldom investigated specific technologies in the auction website context. The investigation of specific technological attributes in auction website is necessary because different websites provide different services to customers. Hence, such research is needed to validate specific IT capabilities in specific IT context that enhance e-customer loyalty.

Second, although reputation has been thoroughly studied, branding itself has been largely ignored. We only found one e-loyalty study that addressed branding [25]. Corporate reputation and branding are both important to marketing [35]. Reputation (or brand image) is a "bottom-up" approach from the customer perspective, whereas branding is a newly developed “top-down” approach from the organizational perspective [36]. With the emergence of website brand effects, more emphasis needs to be placed on website branding than on the traditional branding approaches [16; 37].

Third, in terms of the customer factors, trust and satisfaction have both been examined as intermediaries in many studies. Some researchers called for further research on hedonic and functional 
elements [16]. The aim of this study is to address these research gaps by investigating e-loyalty to online auction websites.

\section{Studies on the S-O-R Model}

The traditional S-O-R model was derived from the input $\rightarrow$ output model, which assumes that individuals make rational behavioural decisions [13]. However, decision making is not a fully rational process, due to people's individual differences and their unique mental states and processes. As people are not entirely rational in their decision-making, the S-O-R model places more emphasis on factors relating to internal organism reactions in explaining individual responses. According to the S-O-R model, environmental stimuli can affect the cognitive and affective reactions that cause individuals to perform certain behaviour [5]. Hence, the S-O-R model solves the "rationality assumption" problem of the original input $\rightarrow$ output model by emphasizing the internal cognitive and affective processes of individuals, which are referred to as organism reactions. Importantly, the S-O-R model considers the organism to be the mediator between the stimulus and the response.

The traditional S-O-R model has been widely used in studies of consumer behaviour (some of the key investigations are summarized in Appendix A). With the exception of [38; 39], all of the existing studies have been conducted in the context of online shopping. However, to the best of our knowledge, no existing S-O-R research has focused on online auction websites. The traditional S-O-R studies used a range of stimulus, organism reaction, and response variables. The most commonly investigated response variables are customer satisfaction, loyalty, and purchase intention. The stimulus variables used to investigate the response variables can be classified as relating to technological, social, and ambience-related factors. In regard to the relationship between the stimulus and response variables, researchers have mainly focused on the emotional and cognitive states of customers. The emotional states that have been investigated include pleasure, arousal, flow, perceived enjoyment, and affect. Cognitive states such as perceived usefulness, cognition involvement, and valence or perceived diagnosticity have also been examined. Most studies [e.g., 6; 38; 40-42] have investigated both of these states. 
All of the aforementioned studies have confirmed the validity of the traditional S-O-R model, and most have tested the mediating effect of the organism on an ad hoc basis using Baron and Kenny’s [43] three-step method. In addition to using the standard S-O-R constructs, some studies have adopted applied personal or situational moderators, such as involvement and atmospheric responsiveness [44], perceptual curiosity [8], involvement and demographic attributes [41], product-related risk [45], and user expertise [9]. In studies of multiple organism constructs, researchers have also examined the interactive effects of the variables [e.g., 7; 38; 39; 41; 42; 44].

The findings of the previous studies suggest that most technology-related stimuli are fully mediated by organism reactions (cognition or affect or both) [6; 7; 38; 44; 45]. However, the findings regarding the effects of ambience-related and social factors are not conclusive. Among the few studies that have explored both the partial and full mediating effects of organism related factors, Mummalaneni [11] found that the mediating effects of emotional responses on shopping behaviour were mixed. Moreover, the effect of design was found to be fully mediated by pleasure and arousal, whereas that of ambience was partially mediated. This inconsistency requires further examination to validate the evolutionary S-O-R model.

\section{The Evolutionary S-O-R Model}

Although people do not behave in a completely rational manner, they are not completely irrational. The concept of bounded rationality is generally held to provide the most realistic account of the decision-making process [46]. Proposed by Herbert Simon, the bounded rationality framework maintains that when people make decisions, their rationality is limited by the cognitive limitations of the decision-maker, the information they possess, and the finite amount of time they have to make a decision [47]. Hence, the assumption that there is a direct relationship between stimuli and responses needs to be re-evaluated. Nonlinear S-O-R relationships can depict the complex and dynamic behaviour of rationally bounded people. Accordingly, Jacoby [13] extended the traditional S-O-R model to formulate an evolutionary S-O-R model. 
Jacoby [13] based the principle of the evolutionary S-O-R model on the fundamental characteristics of the traditional S-O-R model. However, instead of framing the S-O-R relationship in a linear, sequential manner, the evolutionary model depicts S-O-R as three overlapping circles that form a Venn diagram with seven sectors. As indicated in Figure 1, the dashed boundary lines depict the permeable evolutionary relationships between adjacent sectors. Sector 1, the encountered environment, includes a package of external stimuli (such as products, brands, prices, and logos) and represents the environment that individuals encounter in problem solving. When some of these stimuli are processed or responded to automatically or unconsciously, the individual crosses the permeable lines and evolves to either Sector 2 or Sector 5. However, when stimuli are processed and responded to consciously, the individual moves to Sector 4. If the processing and response process is not directly visible and needs to be learnt, the individual moves to Sector 6, which is termed internal responses. It is likely that the outputs from Sectors 2, 4, and 6 shift to Sector 3, which represents the emotive and cognitive faculties along with all of the individual's prior experiences or long-term memories, which thus allow him/her to react appropriately to external stimuli. Sector 7 represents external responses, which refer to externally detectable nonverbal, verbal, and behavioural responses.

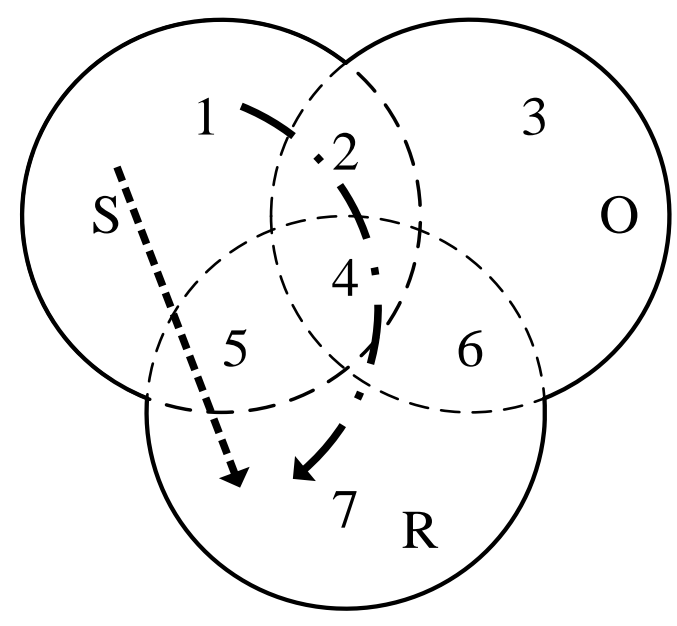

Sector 1: encountered environment;

Sector 2: automatic processing;

Sector 3: experiential storehouse;

Sector 4: consciousness;

Sector 5: untraceable stimulus-response events;

Sector 6: internal responses;

Sector 7: external responses.

$\rightarrow$ the S-O-R path

$-\mathbf{- n - m}$ the direct S-R path

Figure 1. The Evolutionary S-O-R Model 
There are two paths from Sector 1 to Sector 7, the S-O-R path and the direct S-R path in the evolutionary S-O-R model; notably, the traditional S-O-R model only exhibits the first path. One of the aims of this study is to investigate the full and partial mediating effects of organism reactions on the relationship between stimulus and response. The evolutionary S-O-R model, especially the two evolutionary paths from Sector 1 to Sector 7, provides a solid theoretical basis for this investigation. Importantly, we conduct our study in a bidder loyalty context and include a number of technology and brand related factors.

\section{RESEARCH MODEL AND HYPOTHESES}

The research models developed in this study are based on the traditional and evolutionary S-O-R models. In selecting our organism mediators, we concur with the argument by Parboteeah et al. [7] that users' interactions with websites induce both cognitive and affective reactions. The construct of cognitive reactions captures the mental responses to environmental stimuli, whereas that of affective reactions captures the individual's emotional responses [7]. Online bidding not only involves buying things from sellers but also fosters a sense of competitive gaming with other bidders to "win” bids. In fact, research on consumer behaviour in the context of online bidding has shown that most bidders perceive other bidders as competitors, securing a successful bid as “winning," and not achieving a successful bid as "losing” [48]. Such cognitive reactions can have strong hedonic effects on users, whereby the experience of winning (or almost winning) generates emotional and physiological responses, the tension and excitement of which can lift self-esteem and create habits that are centred on the behaviour that created the arousal [49]. Therefore, online auction websites, which are an example of a mixed-motivation system, appeal to both utilitarian and hedonic motivations [50].

In addition, as indicated in Appendix A, the mediating effects of the utilitarian and hedonic factors in previous studies remain uncertain. Some show full mediation while others do not. Therefore, in this study, we examine bidders' perceived bidding utility and enjoyment of a website as the selected cognitive and affective organism reactions. Perceived bidding utility refers to bidders' perceptions of the 
utility of an auction website-including its performance, quality, usefulness, and credibility. Perceived bidding enjoyment refers to their perceived enjoyment of using an auction website, such as good feelings, pleasant memories, and sensory pleasure. The selection of utilitarian-hedonic perception as organism variable is based on the argument that information technology may be classified as utilitarian or hedonic [51; 52]. This classification is shaped by the consumption perspective that distinguishes between cognitive and affective organism reactions to the information technology. That is, the use of website can trigger bidders’ organistic reactions in perceiving the website’s utility and hedonic value in bidding.

In identifying the stimulating cues of auctioning, we started from investigating the factors that lead to the success of websites. Most often, researchers relate these success factors to user perception of the website through the lenses of various adoption theories. A review of these studies suggest that website success factors include website quality [e.g., 37; 53], website service [e.g., 19; 26; 33], website design [e.g., 9; 15], and network effect [e.g., 54; 55].

To understand how cognitive and affective reactions are brought about and sustained over time by these stimulating cues, we first interviewed 21 experienced online users of Taobao (the largest online auction platform in China), and solicited their feedback regarding their use of the auction website. During the interviews, we queried these bidders about the critical functions and features of Taobao that motivated them to continue bidding with this website to obtain more specific, rather than general, factors since there is little relevant information on this in existing literature. The top responses were found to be bidding agent, watch the item (WTI), website popularity and bidder size, and product range. These four responses became the basis of the "stimuli" selected in our study because they outnumbered other functions significantly. The four stimuli were then classified into technological factors (including the effectiveness of bidding agent and WTI) and brand factors (network effect and product diversity) and further introduced below.

The bidding agent allows bidders to automatically update their bids in response to other bids. The WTI function enables bidders to continuously watch their target auctions by automatically sending them 
messages with updates on the progress of each auction. The network effect refers to the economic effect of a product becoming more valuable the more it is used by consumers, as in the cases of the telephone, email, and the Internet, see for example [55-58]. A positive network effect increases bidders' utility when more bidders are bidding in the same auction site. A positive network effect is crucial as it suggests popularity of the website, diversification of products auctioned, potential of more entrants, and extent of services offered. A larger bidder size also leads to more intense bidding and bidding experience sharing, which possibly causes herding or social influence among bidders. To operators of auction websites, the network effect provides an effective basis for strengthening corporate brands in an online environment. Due to the increasing importance of WOM marketing, the network effect is becoming increasingly crucial for the viability of online platforms. The network effect can help online auction websites strengthen their corporate identity and brand and thus help particular websites to become "branded," that is, more attractive and more widely recognized and accepted. Therefore, the network effect is an important factor in online auction website branding.

In addition, the product range offered on an auction website can enhance the stickiness of the website brand. From an organizational perspective, product diversity is significantly related to firm performance, regardless of whether the company is a large firm [59; 60] or a small- or medium-sized firm [61]. From a consumer perspective, variety offers more options for customers to satisfy their needs over time and helps them find products more easily [62]. For online auction websites, product diversity plays an even more important role in branding. The convenience and customization that variety provides have been found to increase e-loyalty [53; 63]. Hence, we selected the network effect and product diversity as the branding stimuli in our model. Compared with the technological factors, the branding stimuli of the network effect and product diversity are less easily imitated by competitors.

The four identified stimuli were selected as the independent variables of our research models and were proposed on the basis of the traditional and evolutionary S-O-R models, with the following adjustments. First, a core assumption of the S-O-R model is that not all the stimuli have consequential 
effects on all the reactions. Second, also based on the S-O-R principles, we assume that the bidders' reactions will exhibit some organismic interactions. These interactions are indicated in the research models. Model 1 is the full mediating model based on the traditional S-O-R model. Models 2 and 3 are partial mediating models based on the evolutionary S-O-R model (see Sector 5 in Figure 1) that assess the direct effects of technological and branding stimuli on bidder loyalty, respectively.

\section{The Full Mediating Model (Based on the Traditional S-O-R Model)}

The full mediating model is depicted in Figure 2. The perceived effectiveness of the bidding agent, WTI, the network effect, and product diversity are the stimuli that influence bidders' organism reactions and their perceptions of the website. These stimuli are all proposed to have a direct effect on perceived bidding utility, but only network effect and product diversity are proposed to have influence on hedonic perception. Bidding agent and WTI are simple software agents with only a few parameters to manipulate. They were designed to automate bidders' tasks and make their bidding process more efficient. Hence, these technologies are more utilitarian in orientation, rather than hedonic in design and use. Past research [e.g., 64; 65] have also confirmed that software tools—-particularly simpler ones—have weaker or even no significant hedonic value than utilitarian value in website acceptance. Therefore, we designed our model to only evaluate the hedonic value of network effect and product diversity.

The bidders’ perceived bidding utility and enjoyment of the online auction website, which represent cognitive and affective reactions, respectively, influence their e-loyalty responses to the website. In this full mediating model, the stimuli do not directly affect the response, as indicated by Figure 2. In the remainder of this section, we provide a detailed account of the hypotheses for this model.

\section{Bidder perceptions and bidder loyalty}

When online auction websites are examined as a technology, three types of perceptions are usually investigated: perceived ease of use, usefulness, and enjoyment. These factors are the major determinants of the technology acceptance model (TAM) [52; 66]. In a recent study, these perceptions were extended to mixed-motive uses that involved both strong utilitarian and strong hedonic motivations 
[50]. The findings of this study coincide with research findings that suggested that two customer perceptions, utilitarian and hedonic, influenced customers’ purchase behaviour [67].

A number of previous studies have confirmed the effects of perceived bidding utility from a

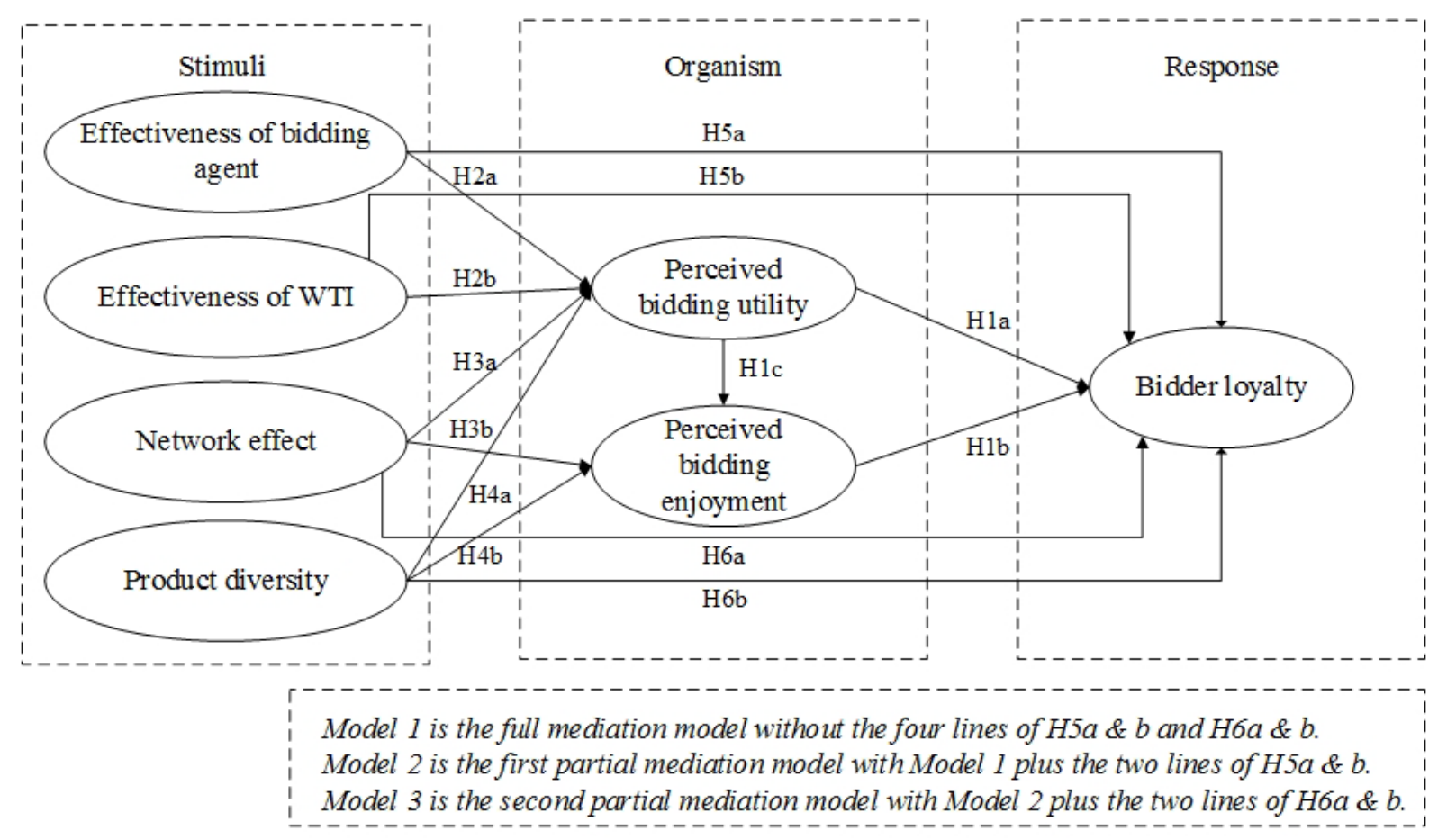

Figure 2. The Research Models

technological perspective. For example, perceived usefulness was found to be positively associated with the intention to use technologies in the TAM [66; 68; 69]. Perceived ease of use and usefulness have also been found to influence e-loyalty [4; 26; 70]. For example, perceived usefulness was found to predict the acceptance of instant messenger services among employees [71]. Perceived website competence was also investigated as a dimension of trust and was found to have a positive influence on website loyalty [20]. In another study, perceived e-service utility was found to have a positive effect on customer loyalty and commitment [72]. Based on these findings, we believe that the same associations apply to online auction websites. Thus,

H1a: Perceived bidding utility is positively associated with bidder loyalty to an online auction website.

In addition to utilitarian factors, hedonic factors have attracted significant research attention [73]. 
Perceived enjoyment, or the extent to which using a system is perceived as pleasurable and fulfilling in itself [68], was introduced in a later version of the TAM and was found to often play a stronger role than utilitarian motivations [50; 52]. For example, studies on online games have shown that perceived enjoyment plays a critical role in the acceptance of gaming systems [74]. Recently, two empirical studies on online gaming adoption and immersion (i.e., hedonic motivations) found that although usefulness is a helpful predictor of the initial use of a game, the key to immersive use is stimulating the gamer's curiosity and joy [50]. Another study found that when users' immersive needs were satisfied, the users became loyal to the gaming system [75]. A study on an online store found that stimulating customers' online enjoyment affected their e-loyalty [19; 70]. Customer satisfaction was also found to affect e-loyalty in an e-banking context [76]. The results of these studies indicate the importance of perceived bidding enjoyment for system use, acceptance, and loyalty.

Perceived bidding enjoyment have been shown to have a positive influence on consumers’ brand satisfaction, which can influence purchase intentions [67]. In addition, consumers’ perceived bidding enjoyment of a brand were found to enhance their intention to purchase products of the brand [67], thereby increasing their customer loyalty. Based on our literature review, we propose that the same relationships hold for online auction websites. Specifically, we believe that the bidders’ perceived bidding enjoyment will enhance their intention to revisit the website, thereby increasing their e-loyalty. Thus,

H1b: Perceived bidding enjoyment is positively associated with bidder loyalty to an online auction website.

In addition to their individual effects on bidder loyalty, customers' cognitive and affective perceptions are likely to interact. Empirical support has been found for a causal relationship from cognition to affect [7] and the reverse relationship has also been supported [77]. It has been speculated that the causal direction between the two variables is determined by the dominant mediating state (either cognitive or affective) in a given context [7]. Prior research has selected effectiveness and enjoyment to represent the cognitive and affective perceptions, respectively [30]. In a utilitarian online auction (rather 
than hedonic), we propose that bidders' perceived bidding utility (i.e., cognition) goes before their perceived bidding enjoyment (i.e., affect). Maslow's theory of hierarchy of needs [78] also suggests that the basic needs (to buy items from sellers) should be fulfilled before the advanced needs (e.g., to "play games” with and beat other bidders) [48]. Yet, fulfilling utilitarian goals can be highly fulfilling [79]. Thus, the bidders’ perceived bidding utility can thus influence their perceived bidding enjoyment. The more utility bidders perceive in an online auction website, the more pleasure they are likely to experience. Thus,

H1c: Perceived bidding utility is positively associated with perceived bidding enjoyment.

\section{Technological stimuli}

A bidding agent is an online system that helps bidders bid automatically after they set a specific reserve price [80]. Typically the bidding agent continues to outbid any other bidders, but only with a minimum bid increment, until it reaches the reserve price. In this way, bidders do not have to wait and respond to any further bids from others, which helps to save time. This process can also guarantee that the bidder do not lose the consumer surplus if winning the auction because the final price is lower than or at most equal to their willingness-to-pay. In addition, before a bidder actually submits a bid on an item in which they are interested, the WTI function can enable them to watch the auction process. WTI also allows bidders to watch multiple items at the same time, thereby freeing the bidders from having to check the individual webpages. The WTI function automatically sends messages to potential bidders with updates on the auction process. Accordingly, the bidding agent and WTI directly affect the bidding performance of users more than other services. Importantly, the use of these functions decreases the cognitive load of engaging in online auctions and increases the bidders' chances of winning. We propose that like website navigation and accuracy in general, these specific technological stimuli strongly influence customers' perceived bidding utility. Thus,

H2a: The effectiveness of the bidding agent is positively associated with the perceived bidding utility. 
$H 2 b$ : The effectiveness of the WTI function is positively associated with the perceived bidding utility.

\section{Branding Stimuli}

According to the traditional S-O-R model, individuals' cognitive/affective reactions are aroused by stimuli. We argue that the network effect is another important stimulus that can influence bidders' perceptions. The network effect is directly related to customer utility because the greater a network's size, the greater its value to customers [81]. For example, the network effect of broadband infrastructure has been demonstrated in many countries [82]. Similarly, the network effect has been shown to lead to higher software value [83] and to result in increased profit for software vendors [84]. It has also been proposed that successful online auction websites exhibit a network effect that qualitatively increases their overall value and helps them quickly overwhelm their competition [54]. We thus propose that the network effect can be perceived by bidders from the customer perspective, especially as they discover the depth and breadth of the network through using and interacting with a website. That is, the larger the perceived network effect of an online auction website, the greater the online bidders' perceived utility:

H3a: The network effect is positively associated with the perceived bidding utility.

Moreover, we propose that the network effect influences bidders’ perceived bidding enjoyment, not just their perceived bidding utility. As humans are social animals, individuals need to interact with others. The network effect is based on the extensive online user base, which brings more social presence and social norms to the network that can affect bidders' perceived bidding enjoyment. The social presence of others was found to increase customers' perceived enjoyment of a B2C e-service [70]. Social norms were also found to positively affect the perceived enjoyment of technologies [85]. In online auctions, social presence was found to increase bidders' participation behaviour [86], and the network effect enhanced sellers' perceived enjoyment [87]. In fact, some auction websites have even organized their members into social groups, allowing them to exchange bidding information and experience [33]. With these social groups, bidders are organized into friends at the personal and bidding levels, which increases 
interaction, fun, and pleasure [88]. Given these findings, we propose that the network effect also enhances bidders’ perceived enjoyment because it increases the possibility of interaction, competition, and cooperation with others as well as the joy inherent in these forms of social engagement. Thus,

H3b: The network effect is positively associated with the perceived bidding enjoyment.

Product diversity is significantly related to firm performance regardless of company size. The development of the Internet has transformed product distribution and affected product diversity [89]. In the context of online auction websites, it has been argued that product diversity is important for attracting customer interest and is a critical consideration for auction intermediaries attempting to establish a website brand [90]. Greater diversity offers more convenience and options for bidders, which can increase their perceived bidding utility of an auction website. Research has shown that the increased product variety of online bookstores can enhance consumers’ welfare [91], which may affect their perceived bidding utility. Thus,

H4a: Product diversity is positively associated with the perceived bidding utility.

People often exhibit variety-seeking behaviour [92], which suggests that variety may be a key source of hedonic motivation. In the hedonic adaptation prevention model, variety is considered the “spice” of happiness [93]. We believe that this explanation can be generalized to the online auction website context, in which product diversity is likely to be associated with bidders' emotional reactions. Higher diversity may lead to more searches, comparisons, and competition between products [63], which increase the pleasure of bidding online. From a consumer behaviour perspective, variety is important because the many choices satisfy the purchaser's need for stimulation [62]. This is a key factor for traditional retailers and it explains why consumers enjoy large malls and a wide variety of shopping choices [94]. Considering the similarity between online bidding and online shopping, variety-seeking behaviour should apply to the users of online auctions. Thus,

H4b: Product diversity is positively associated with the perceived bidding enjoyment.

\section{Partially Mediating Models (Based on the Evolutionary S-O-R Model)}


Sector 5 in the evolutionary model indicates that there may be a relationship between a stimulus and a response due to the individual's “chemical response.” In this situation, the organism may only partially mediate the effect of the stimulus on the response. To confirm the direct effect of stimuli, we propose two partially mediating models. The first alternative model (Model 2) tests the partial mediating effect of customer perception on the relationship between the effectiveness of technological services and bidder loyalty. In this model, the direct paths from the effectiveness of the bidding agent and WTI to bidder loyalty are added to the full mediating model (Model 1). The more effective the two technological services are, the more loyal the customers will be to the auction website. Thus,

H5a: The effectiveness of the bidding agent is positively associated with bidder loyalty.

H5b: The effectiveness of the WTI function is positively associated with bidder loyalty.

Model 3 tests the partial mediating effect of customer perception on the relationship between branding stimuli (the network effect and product diversity) and bidder loyalty. The corresponding paths between the two stimuli and bidder loyalty are thus added to the model. The network effect has been found to have a direct effect on behaviour. For example, the network effect was found to be a significant driver of the adoption of open-standard inter-organizational systems [57]. Cheng and Liu [58] empirically confirmed that the network effect can deter mobile telecommunication users from switching to another carrier. The perceived network effect was also found to positively affect sellers' intentions to use an online auction website [95]. In addition, because people tend to exhibit variety-seeking behaviour [62], customer loyalty is likely to be increased if consumers' needs for convenience and customization are fulfilled by obtaining diverse products [53; 63]. In line with this, a study confirmed that the width of product selection had a positive effect on e-loyalty [15]. Thus,

H6a: The network effect is positively associated with bidder loyalty.

H6b: Product diversity is positively associated with bidder loyalty.

\section{METHODOLOGY}

\section{Measurement Development}


Most of the measurements used in this study were developed based on previous literature. The review process allowed research variables to contain the basis for measurement development and reliability assurance. All of the measures were composed of multiple statements in which the respondents were asked to respond using a 7-point Likert scale, ranging from 1 (“strongly disagree”) to 7 (“strongly agree”). Importantly, as discussed in the next section, all of the measures were rigorously processed to establish their content validity, including a pilot test of their reliability.

We developed the measures of the effectiveness of the bidding agent and the effectiveness of WTI on the basis of the study by Pavlou and Gefen [96], in which the perceived effectiveness of the feedback mechanism was measured by investigating its accuracy, availability, effectiveness, and reliability. Pavlou and Gefen also measured the perceived effectiveness of escrow services by examining the guarantees provided by their functions. In this study, we used the effectiveness, reliability, service quality, and function guarantees to measure the effectiveness of the bidding agent and WTI.

We based the measure of the network effect on the findings that a growing network can lend more "utility," "benefit,” and “value” to the next participant [57; 97; 98]. In this study, the network effect was thus measured by these three items, together with “convenience,” which is also a critical dimension of the network effect [99].

We developed the measure of product diversity based on the measures used in previous studies [89; 91]. The product diversity measure included four statements asserting that the products being auctioned were of great quantity and variety and affirming that the website provided sound choices and better inventory than other auction sites.

We adapted the measures of perceived bidding utility and perceived bidding enjoyment from a study by Na et al. [67] by changing the word "product brand” to "website.” Hedonic perception was measured using indicators of good feelings, pleasant memories, and sensory pleasure. Perceived bidding utility was measured using performance, quality, usefulness (added), helpfulness, and the credibility of the website's image. 
We adapted the measure of bidder loyalty from [70; 100]. Cyr et al. [70] measured perceived loyalty by website reuse behaviour. We extended their measure by dividing reuse into frequent and regular future bidding on the website. In addition, according to Lam et al. [100], loyalty includes not only the patronage of an online vendor but also confidence in recommending the vendor. Therefore, we added a statement regarding recommendations to others to this measure.

\section{Measurement Content Validity}

We established content validity through several rigorous scientific procedures. First, most of the measures were based on previously validated instruments that adhere to the guidelines for online instrument construction [101]. Second, the questionnaire was initially developed in English and subsequently translated into Chinese by a doctoral student. A second doctoral student was invited to translate the Chinese version back into English. The original English and the translated versions were then compared by a professor to check for accuracy. This process enabled us to establish a cross-cultural measurement equivalent, as shown in [102]. Thus, the early version of the questionnaire was refined multiple times to ensure content validity.

Third, the questionnaire was pretested by four business professors with experience in IS survey research and 20 experienced online bidders. Based on their feedback and comments, changes were applied to the wording, grammar, and structure of the questionnaire to reduce ambiguity and improve readability. Moreover, the question sequence was rearranged to ensure questionnaire validity and reliability.

Finally, a pilot study was administered to 25 online bidders randomly chosen from the largest online auction website in China, Taobao. Cronbach's alphas for all of the items in the pilot test were above or near 0.80, indicating that the questionnaire had adequate reliability [103]. As a result of the pilot test, a few changes were made to the wording and sentence structure of the questionnaire, which further improved the content validity of the survey instrument.

\section{Data Collection}


The data for this study were collected from the Taobao auction website. We randomly chose 1,299 bidders on the website. To avoid contaminating the data with fake IDs, only validated bidders whose identities were verified by Taobao were selected. The bidders were contacted through the online WangWang instant messenger service and were given a brief introduction to the study, which included a description of the research objectives and requirements and an invitation to participate. The participants were given a reward of 10RMB (approximately US\$1.64) following successful completion of the online survey.

The bidders who agreed to participate were asked to complete an online questionnaire on the website of a professional online survey firm (www.surveymonkey.com). The use of this service guaranteed access control, authentication, and the avoidance of multiple responses from the same respondents [104]. After two rounds of reminders, 449 bidders completed the questionnaire and their responses were automatically collected by the online survey.

\section{RESULTS}

\section{Respondent Profile}

Of the 449 respondents, 130 (29\%) were male and 319 (71\%) were female. This gender ratio was consistent with a report by the China Internet Network Information Centre indicating that the male-to-female ratio of Taobao users is 39.3:60.7. ${ }^{1}$ Most of the respondents (44.4\%) were between 25 and 30 years old, 28.3\% were between 19 and 24 years old, 21.4\% were between 31 and 38 years old, and all other age groups accounted for less than $10 \%$ of the respondents. Most of the respondents, $78.4 \%$, had a university-level education, $11.6 \%$ had a high school education, and those with less education comprised less than $10 \%$ of the sample. Regarding income, $27.7 \%$ of the respondents earned less than 2,000RMB (US\$329) per month, 39.7\% earned 2,001RMB to 4,000RMB (US\$330 to US\$658) per month, 20.9\%

\footnotetext{
${ }^{1}$ http://www.cnnic.net.cn/research/bgxz/dzswbg/200912/t20091203_18410.html;
} http://blog.sina.com.cn/s/blog 5101b9050100hvz8.html 
earned 4,001 to 6,000RMB (US\$659 to US\$988) per month, and 11.6\% earned more than 6,001RMB (US\$988) per month. In terms of employment, the most frequently reported occupations were government or public employee (21.4\%) and student (15.7\%).

\section{Establishing Construct Validity and Reliability}

Prior to running the final models, we conducted tests to establish the construct validity of the questionnaire items. A confirmatory factor analysis (CFA) [105] was conducted using LISREL 8.51 to test the fit of the measurement model. The chi-square value was found to be 986.12 ( $\mathrm{df}=329$ ), the nonnormalized fit index (NNFI) was 0.97 (> 0.95), the comparative fit index (CFI) was $0.97(>0.95)$, the standardized root mean residual (SRMR) was $0.044(<0.06)$, and the root mean square error of approximation (RMSEA) was $0.071(<0.08)$. The indices met the cut-off criteria for the measurement model [106; 107], indicating that the measurement used in this study had good fit. Convergent validity was established by the good-fit indices of the measurement model, the item loadings (all higher than 0.5), and the average variance extracted (AVE) values of the constructs (all of which were above the 0.5 threshold [108]).

Discriminant validity was assessed by comparing the square roots of the AVE values and the correlations between the constructs. As shown in Table 2, the correlation of each pair (off-diagonal) was smaller than the square root of the AVE of each of the constructs. Thus, discriminant validity was confirmed. To further assess the discriminant validity, a series of constrained CFA models was developed to compare with the original unconstrained CFA model [109]. In each constrained model, the correlation between one pair of constructs was constrained to 0.7 .

Discriminant validity was tested by the chi-square change caused by the constraint tests. A significant change meant that the correlation of the two constructs was significantly different from 0.7. Our data analysis results demonstrated that the correlations between each pair of constructs were all significantly different from 0.7, confirming discriminant validity. We also calculated Cronbach's alpha to test the reliability of the measurement ( $\alpha$ in the first column of Table 2). Most of the Cronbach's alpha values 
were above or close to 0.9 , except for the value for bidder loyalty, which was 0.731 (still above the standard threshold).

The common-method variance (CMV) was also examined by using Harman’s single-factor test, in which all of the items were included in an exploratory factor analysis. The un-rotated solution generated seven factors rather than one single factor, and the first factor did not account for the majority of the variance (33.6\%), indicating that no serious CMV was likely in our study. In addition to Harman's test, we checked the correlation matrix. There were no high correlations ( 0.90 or above), which also confirms that CMV was not a problem in this study [110]. 
Table 2. Measurement Model Statistics

\begin{tabular}{|c|c|c|c|c|c|c|c|c|c|c|c|}
\hline Latent Construct & $\alpha$ & Mean & SD & AVE & (1) & $(2)$ & (3) & (4) & (5) & (6) & (7) \\
\hline $\begin{array}{l}\text { Effectiveness of } \\
\text { bidding agent (1) }\end{array}$ & 0.927 & 20.91 & 4.68 & 0.768 & $\underline{0.876}$ & & & & & & \\
\hline $\begin{array}{l}\text { Effectiveness of } \\
\text { WTI (2) }\end{array}$ & 0.870 & 22.97 & 3.52 & 0.645 & 0.261 & $\underline{0.803}$ & & & & & \\
\hline $\begin{array}{l}\text { Network effect } \\
\text { (3) }\end{array}$ & 0.912 & 22.58 & 3.88 & 0.730 & 0.306 & 0.412 & 0.854 & & & & \\
\hline $\begin{array}{l}\text { Product diversity } \\
\text { (4) }\end{array}$ & 0.926 & 24.03 & 2.86 & 0.768 & 0.104 & 0.152 & 0.312 & $\underline{0.876}$ & & & \\
\hline $\begin{array}{l}\text { Perceived bidding } \\
\text { utility (5) }\end{array}$ & 0.907 & 28.56 & 4.19 & 0.670 & 0.362 & 0.476 & 0.603 & 0.281 & $\underline{0.819}$ & & \\
\hline $\begin{array}{l}\text { Perceived bidding } \\
\text { enjoyment (6) }\end{array}$ & 0.873 & 22.07 & 3.82 & 0.648 & 0.334 & 0.446 & 0.521 & 0.314 & 0.637 & $\underline{0.805}$ & \\
\hline Bidder loyalty (7) & 0.731 & 18.26 & 2.37 & 0.540 & 0.246 & 0.354 & 0.458 & 0.322 & 0.469 & 0.521 & $\underline{0.735}$ \\
\hline
\end{tabular}

We also tested the multicollinearity of the variables by examining their variance inflation factors

(VIFs). They were all between 1.108 and 2.796, far below 5, which indicated there is no serious

multicollinerarity among the variables.

\section{Results of the Structural Equation Models}

We used covariance-based SEM (CB-SEM) for model testing, because it allowed the model differences to be tested by comparing the model fit indices, which was necessary for comparing the alternative models in this study [110]. Using LISREL 8.54, we first ran the SEM for Model 1 (see Figure 3). The model fit indices were as follows: chi-square $=1030.41(\mathrm{df}=335), \mathrm{RMSEA}=0.072(<0.08)$, NNFI $=0.97(>0.95), \mathrm{CFI}=0.97(>0.95)$, and standardized RMR $=0.052(<0.06)$. All of these indices were better than the recommended values [106; 107]. The explanatory power of the research model was also high, with a bidder loyalty $R^{2}$ of $47 \%$. We also controlled the gender, age and education in the model test and none of the control variables had a significant effect on the bidder loyalty.

The results of Model 1 support hypotheses H1a, H1b, and H1c, thereby confirming the effects of perceived bidding utility and enjoyment on bidder loyalty. The relationship between perceived bidding utility and enjoyment is also verified; perceived bidding utility not only has a direct effect on bidder loyalty but also has an indirect effect through perceived bidding enjoyment. 


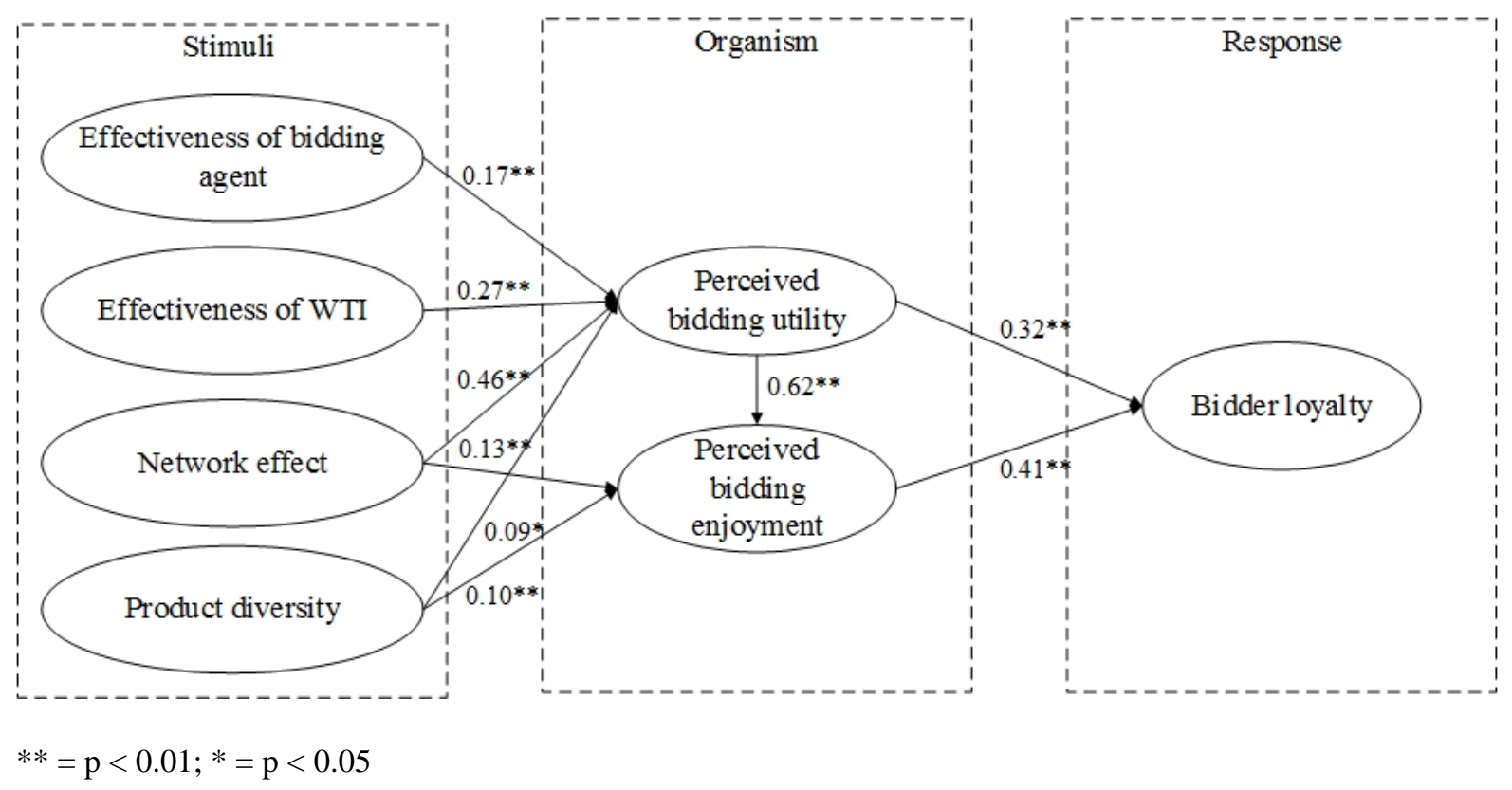

Figure 3. SEM of Model 1 (The Full Mediation Model)

The two hypotheses concerning the effect of technological stimuli on perceived bidding utility (H2a and H2b) are supported. The results show that the effectiveness of an online auction's technological services significantly enhances bidders’ perceived bidding utility of the website. The network effect, on the other hand, significantly influences both utilitarian and enjoyment perception, as indicated by the support for H3a and H3b. Regarding the influence of product diversity, although the standardized coefficients for utilitarian and enjoyment perception are not large (0.09 and 0.10), the relationships are still statistically significant, at $p=0.05$. Both H4a and H4b are supported. The more diversified the products are, the more utility and enjoyment the customers perceive regarding the website.

Moreover, we found that the weights of technological and network effect were stronger in the relationship with bidders' perceived utility than on their perceived enjoyment. These findings suggest that auction websites, within the context of our study, are perceived by bidders as more utilitarian than hedonic. Consequently, per [79], these are mixed-motive systems that still have to account for enjoyment.

\section{Comparison with Alternative Models}

To test whether Model 1 represents the best fit, the two alternative models were also analysed by 
the CB-SEM and compared with Model 1. The differences in the model fit indices were calculated together with the $R^{2}$ changes in Table 3; this approach has been used in previous studies [21; 50]. These comparisons show that Model 2 does not significantly improve Model 1. The chi-square change is insignificant. Although the SRMR drops slightly, the RMSEA increases and the $R^{2}$ of bidder loyalty remains the same, indicating that adding the direct effect of the two technological stimuli on bidder loyalty does not notably improve the model. In terms of model parsimony, Model 1 outperforms Model 2. Consumer perceptions fully mediate the relationship between the effectiveness of technological services and bidder loyalty. H5a and H5b are not supported.

Table 3. Chi-Square Differences in the Model Fit of the Three Models

\begin{tabular}{llllllllll}
\hline Models & $\begin{array}{l}\text { Chi- } \\
\text { square }\end{array}$ & df & $\begin{array}{l}\text { Delta Chi- } \\
\text { square }\end{array}$ & RMSEA & NNFI & CFI & SRMR & $\begin{array}{l}R^{2} \text { of } \\
\text { Bidder } \\
\text { loyalty }\end{array}$ & Delta $R^{2}$ \\
\hline Model 1 & 1030.41 & 335 & & 0.072 & 0.97 & 0.97 & 0.052 & $47 \%$ & \\
Model 2 & 1025.16 & 333 & 5.25 & 0.073 & 0.97 & 0.97 & 0.051 & $47 \%$ & 0 \\
Model 3 & 1008.24 & 333 & $22.17^{* *}$ & 0.071 & 0.97 & 0.97 & 0.048 & $50 \%$ & $3 \% * *$ \\
\hline
\end{tabular}

However, Model 3 shows a significant improvement over Model 1, with a statistically significant chi-square change ( $p<0.01)$, a statistically significant increase in the $R^{2}$ of bidder loyalty $(p<0.01)$, and slight decreases in RMSEA and SRMR $(0.072 \rightarrow 0.071$ and $0.052 \rightarrow 0.048$, respectively). The results indicate that the direct effects of the two brand stimuli on bidder loyalty cannot be ignored. A further regression test based on [43] was also performed. First, all of the stimuli (including technological and brand factors) are found to be significantly related to bidder loyalty $(p<0.01)$. Second, the stimuli are significantly related to consumer perceptions, which are also significantly related to bidder loyalty ( $p<$ 0.01). Third, when consumer perceptions were introduced into the regression of bidder loyalty on the stimuli, the coefficients of the technological factors become insignificant $(p>0.05)$, and those of the brand factors remain significant $(p<0.01)$. All of the results indicate that consumer perceptions only partially mediate the relationship between brand stimuli and bidder loyalty. Further examination of the results in Model 3 and Figure 4 shows that H6a and H6b are both supported with significant coefficients. 


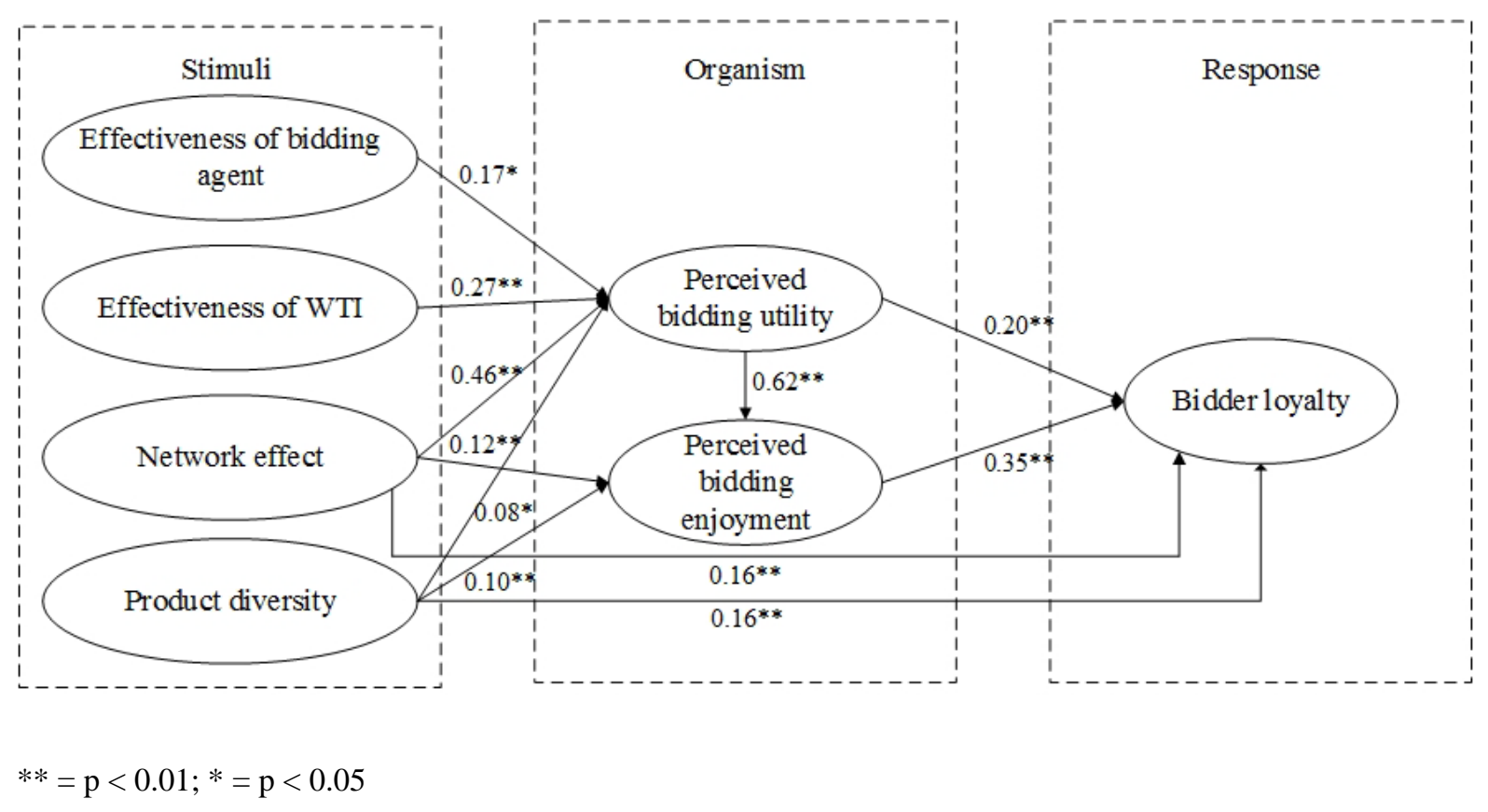

Figure 4. SEM of Model 3 (The Partial Mediation Model)

\section{DISCUSSION AND IMPLICATIONS}

\section{Discussion of the Results}

The results of our data analyses demonstrate that Model 3, which was based on the evolutionary S-O-R model, is the most effective in explaining bidder loyalty. Importantly, our tests confirm several important results that answer our research questions, including the different patterns of the technological and brand factors and the comparison between the traditional and evolutional S-O-R models. In addition, we also discuss the relationship between organism and response and that between cognitive and affective organisms that can further extend the research scope in the future.

First, H5a and H5b were not supported, suggesting that the relationship between the specific technological factors and bidder loyalty is fully mediated by the bidders’ organism reactions. Previous research found the general technology-related factors have the same pattern as we reviewed in the research background section. Therefore, whether specific or general, technological stimuli in e-commerce affect consumers' purchase intentions and bidder loyalty indirectly through their organism reactions 
(cognitive and affective). The results also indicate that technological stimuli usually do not directly lead to performance improvement, as their effects are indirect. In this case, the traditional S-O-R model provides the ideal explanation for this phenomenon.

Second, the partial mediation of bidders' organism reactions between branding stimuli and bidder loyalty is consistent with prior findings [e.g., 11] that indicate that the effect of ambience on loyalty is only partially mediated by the organism. In addition to technology-related stimuli, non-technological issues have become increasingly important in online contexts. For example, in our study, the total effect of the network effect on bidder loyalty is 0.394 , the highest factor in the model. Its direct effect on perceived bidding utility is bigger than that on perceived bidding enjoyment ( 0.46 vs. 0.12 ), likely because network effect is a utility-based concept. The patterns of branding stimuli differ from the patterns of technological stimuli. We found indirect effects on the response variable through the bidders' organism reactions and direct effects without any mediators. The network effect and product diversity can directly increase bidders' e-loyalty in some instances, just as a man might automatically loosen his tie when the temperature in a room increases past a certain point [13].

Third, in addition to confirming the two major paths from stimuli to response (through Sectors 4 and 5, please refer to Figure 1), our study shows that the two other sectors in the evolutionary S-O-R model that involve relationships—Sectors 2 and 6—need further explanation. For instance, after processing stimuli from Sector 1, the utility and enjoyment perceptions evolve into bidder loyalty (Sector 4). However, the experience of the stimuli may also cause the memories of online bidding to accumulate (Sector 2), which do not evolve into a response sector but only remain in the long-term memory organism state (Sector 3). Similarly, the effects of bidders' utility and enjoyment perceptions do not all lead to the easily detected external response of bidder loyalty. Some internal responses, such as the satisfaction indicated in Sector 6, can arise at the same time [19]. Given our strong theoretical foundation, our rigorous model confirmation process, and the actual results, we demonstrated that in our context, the evolutionary S-O-R model better explains the actual development of bidder loyalty than the traditional 
S-O-R model.

In addition to answering our research questions, we also made further discussions. Our partial mediation models confirmed the direct relationship between organism and response in the evolutionary S-O-R model. However, we believe that this relationship may be subject to other variables. For example, in a study investigating repurchasing intentions, the effect of perceived website quality, as a second-order factor, included both navigational quality and utilitarian and enjoyment quality was found to be partially mediated by an intermediary variable, trust [21].

Finally, the results of this study confirm that perceived bidding utility has a significant effect on enjoyment perception (with a standard coefficient of 0.62). Although the mediating effect of perceived bidding utility seems less strong than that of perceived bidding enjoyment, part of the effect of perceived bidding utility on bidder loyalty is actually indirect through perceived bidding enjoyment. In utilitarian-motivation or mixed-motivation systems (such as the online auction website in this study), users are usually motivated by a primary utilitarian purpose (such as purchasing or bidding on a specific item) rather than having fun, although hedonic motivations can influence the results [79]. Thus, their perceived enjoyment arises while using the system. Likewise, in mixed-motivation systems, the cognitive state of the users often influences their affective state. Conversely, in hedonic- or enjoyment-motivation systems (such as online games), the initial motivation of the users is usually to have fun [50], which then affects perceived utility (in our case, bidding utility) [71]. Sometimes, affect may also influence cognition in a utilitarian-motivation system. For instance, researchers [e.g., 111] argued that enjoyment can facilitate completion of product-acquisition tasks, thus increasing shoppers' utilitarian value. An example is that bargains create price discounts, which can positively affect shopping value and its consequential effect on utilitarian value. However, such a reverse relationship mainly exists in some specific situation when the affect-related action can lead to a utilitarian outcome and people should be cautious to generalize it to any other context.

\section{Implications for Research and Practice}


The findings of this study provide insights for both researchers and practitioners interested in bidder loyalty. First, our study contributes to the theoretical literature on e-commerce and information systems by comparing the traditional and evolutionary S-O-R models to investigate the mediating effect of bidders’ organism reactions on the relationship between auction stimulus and bidder loyalty response. The study provides further validation of the usefulness of the two types of S-O-R models in an e-auction context-particularly in China. Moreover, it also contributes to the evolution of the S-O-R model by identifying different patterns of stimuli (specific technological and brand factors) towards response. We advocate that more attention should be paid to the evolutionary S-O-R model in this area, especially with the increasing ubiquity of the Internet in people's lives. Vodanovich et al. [112] raised research questions about the new generation of digital natives, who "have grown up in a world where the use of information and communications technology is pervasive and ubiquitous. The ubiquitous technologies, networks, and associated systems have proliferated and have woven themselves into the very fabric of everyday life” (p. 711). These digital natives are becoming the major consumers and may not share the same patterns of using information technology as the current generation (called digital immigrants). In addition to technology, other factors may also emerge and influence the effect of the growing network environment. Accordingly, new research questions related to these factors should be asked and new models should be developed.

In addition, the findings of this study successfully address the research gaps in the bidder loyalty literature outlined in the background section by investigating (1) specific technological stimuli, (2) website branding stimuli, and (3) customers' hedonic and functional reactions, and by confirming their combined influence on bidder loyalty. Finally, the results of this study confirm the importance of bidders’ e-loyalty to online auction websites, a topic which will attract more studies in the future. A number of studies have investigated bidder loyalty to websites such as online stores [19; 113], hotel-owned websites [25], Internet banking [18], and social media [24]. However, the literature lacks studies on bidders' e-loyalty to auction websites. 
Our findings also provide some insights for online auction website practitioners. For example, our results confirm that in our context, the perceived bidding utility of online auction websites is an important factor in increasing the number of website visits. Perceived bidding utility not only directly affects bidders' e-loyalty but also strongly affects their perceived bidding enjoyment, which also positively influences their e-loyalty. In addition to increasing the perceived bidding utility of bidders, practitioners need to enhance the bidders' perceived bidding enjoyment (the standardized coefficient of 0.35 for perceived bidding enjoyment is even higher than the 0.20 for perceived bidding utility), which echoes the findings of previous research that perceived enjoyment plays an important role in the adoption of technologies with network externalities [85]. Therefore, practitioners need to improve the effectiveness of their technological and brand services to enhance the utilitarian and hedonic perceptions of bidders.

This study identifies the two important technological stimuli that are specific and unique to online auction websites, namely, the effectiveness of bidding agent and WTI, based on the interview of the online bidders. The quantitative analysis also confirms their significant effects on the perceived bidding utility and enjoyment. Online auction website owners should pay attention to the capabilities of these technological services to increase the e-loyalty of the customers. Bidders may not require sophisticated technology support in their bidding process. However, technologies made available to them must fit their bidding tasks. Hence, auction operators may look into technologies that personalize bidders' experience and offer a better sense of playfulness and interaction. They can also develop technologies that monitor website use and behaviour analysis to determine bidders needs and transaction status. All these technologies could provide data to base their technologies to offer personalized services to enhance bidders loyalty.

Among the branding stimuli, the network effect had the biggest effect on perceived bidding utility in our context. Should this continue to hold, extra attention should be given to strengthening the network effect to sustain the competitive advantage of a website. Measures should also be taken to guarantee the successful achievement of critical mass and to maintain a high-level network effect to increase bidders' 
e-loyalty. These measures must address management solutions to network size and network strength. One way to build network size is to leverage extrinsic customer motivation by using promotions or discounts to attract more sellers to an auction website, encouraging sellers to provide more auction items, and launching of marketing branding campaigns. The other way is to rely on intrinsic customer motivation by providing incentives to existing customers for positive WOM referrals, building social platforms for bidders to discuss their bidding experiences, and launching social marketing campaigns to secure and maintain customer engagement. While building network size, website owners also need to strengthen the ties of their network for customer retention and loyalty. In doing so, website owner can organize auction members into different friend or group types according to their background and interest. Within each friend group, opinion leaders can be identified to manage bidding or influence relational activities. Website owner can also set up different social platforms (such as forums, blogs, social networks) to support different social activities to fulfil network members’ relational needs.

\section{Limitations and Future Research Possibilities}

Despite our strong findings, this study has several important limitations that point to opportunities for future research. First, our study did not control for CMV in the research design and we used the Harman's single-factor test, rather than the common latent factor analysis to test the CMV. Although it is possible that CMV could be affecting our results, it likely is not a very serious problem because the correlations were all reasonably low and our data showed no signs of multicollinearity.

Second, we did not investigate the antecedents of the network effect. The network effect plays an important role, as shown in our model, in predicting bidder loyalty. Therefore, more research is needed to reveal the underlying factors that may influence the network effect in online auctions. It would be particularly interesting to examine the degree to which branding and positive WOM increase the network effect.

Third, we mainly focused on the mediating effect of bidders' organism reactions and did not fully investigate other relationships indicated by the evolutionary S-O-R model. Although Jacoby [13] 
permitted "countless numbers of modifications, additions to, and deletions from, each of these seven sectors” (p. 56) and stated that “other core phenomena can be conceptualized as occurring primarily within a single sector” (p. 55), studies focusing on other sectors in the evolutionary S-O-R model should be conducted to provide further validation of the applicability of the model in the e-commerce context.

Finally, because the data used in this study were collected from the largest online auction website in China, caution should be taken when generalizing the research findings to other contexts. For example, although our chosen auction website is technologically similar to several other websites around the world, such as eBay, it is possible that cultural differences between Chinese and non-Chinese bidders would lead to different outcomes if the evolutionary S-O-R model were applied in a non-Chinese context. The substantial research on the use of technology and online systems has indicated that such cultural differences can affect outcomes [102; 114; 115].

\section{CONCLUSION}

In this study, we investigated the mediating effect of bidders’ organism reactions on the relationship between website stimuli and bidders' e-loyalty to online auction websites. We compared three models that we constructed based on the traditional and evolutionary S-O-R models. Our findings confirmed the relationship between stimuli, organism reaction, and response. Specific technological stimuli (the effectiveness of the bidding agent and of the WTI function) and branding stimuli (the network effect and product diversity) were found to influence the perceived bidding utility and enjoyment of bidders and their e-loyalty to online auction websites. Moreover, bidders’ organism reactions were found to fully mediate the effect of specific technological factors but to only partially mediate the brand factors. The results of this study provide a foundation for several areas of future research concerning online auction bidder loyalty.

\section{REFERENCES}

[1] B.B. Stern, M.R. Stafford "Individual and social determinants of winning bids in online auctions," Journal of Consumer Behavior (5:1), 2006, pp. 43-55.

[2] Z. Yang, R.T. Peterson "Customer perceived value, satisfaction, and loyalty: The role of switching costs," 
Psychology \& Marketing (21:10), 2004, pp. 799-822.

[3] Y. Yi, H. Jeon "Effects of loyalty programs on value perception, program loyalty, and brand loyalty," Journal of Academy of Marketing Science (31:3), 2003, pp. 229-240.

[4] M. Gommans, K.S. Krishnan, K.B. Scheffold "From brand loyalty to e-loyalty: A conceptual framework," Journal of Economic and Social Research (3:1), 2001, pp. 43-58.

[5] A. Mehrabian, J.A. Russell An Approach to Environmental Psychology, MIT, Cambridge, MA, 1974.

[6] Z. Jiang, J. Chan, B.C.Y. Tan, W.S. Chua "Effects of interactivity on website involvement and purchase intention," Journal of the Association for Information Systems (11:1), 2010, pp. 34-59.

[7] D.V. Parboteeah, J.S. Valacich, J.D. Wells "The influence of website characteristics on a consumer's urge to buy impulsively," Information Systems Research (20:1), 2009, pp. 60-78.

[8] D.-M. Koo, S.-H. Ju "The interactional effects of atmospherics and perceptual curiosity on emotions and online shopping intention," Computers in Human Behavior (26:3), 2010, pp. 377-388.

[9] P. Song, C. Zhang, P. Zhang "Online information product design: The influence of product integration on brand extension," Decision Support Systems (54:2), 2013, pp. 826-837.

[10] V.A. Vieira "Stimuli-organism-response framework: A meta-analytic review in the store environment," Journal of Business Research (66:9), 2013, pp. 1420-1426.

[11] V. Mummalaneni "An empirical investigation of web site characteristics, consumer emotional states and on-line shopping behaviors," Journal of Business Research (58:4), 2005, pp. 526-532.

[12] D.C.L. Thang, B.L.B. Tan "Linking consumer perception to preference of retail stores: An empirical assessment of the multi-attributes of store image," Journal of Retailing and Consumer Services (10:4), 2003, pp. 193-200.

[13] J. Jacoby "Stimulus-organism-response reconsidered: An evolutionary step in modeling (consumer) behavior," Journal of Consumer Psychology (12:1), 2002, pp. 51-57.

[14] X. Zhao, J.G. Lynch Jr., O. Chen "Reconsidering Baron and Kenny: Myths and truths about mediation analysis," Journal of Consumer Research (37:2), 2010, pp. 197-206.

[15] D. Cyr "Modeling web site design across cultures: Relationships to trust, satisfaction, and e-loyalty," Journal of Management Information Systems (24:4), 2008, pp. 47-72.

[16] E. Toufaily, L. Ricard, J. Perrien "Customer loyalty to a commercial website: Descriptive meta-analysis of the empirical literature and proposal of an integrative model," Journal of Business Research (66:9), 2013, pp.

1436-1447.

[17] A.C.R. van Riel, V. Liljander, P. Jurriëns "Exploring consumer evaluations of e-services: A portal site," International Journal of Service Industry Management (12:4), 2001, pp. 359-377.

[18] S.M. Salmen, A. Muir "Electronic customer care: The innovative path to e-loyalty," Journal of Financial Services Marketing (8:2), 2003, pp. 133-144.

[19] J. Semeijn, A.C.R. van Riel, M.J.H. van Birgelen, S. Streukens "E-services and offline fulfilment: How e-loyalty is created," Managing Service Quality (15:2), 2005, pp. 182-194.

[20] C. Flavián, M. Guinalíu, R. Gurrea "The role played by perceived usability, satisfaction and consumer trust on 
website loyalty," Information \& Management (43:1), 2006, pp. 1-14.

[21] I. Qureshi, Y. Fang, E. Ramsey, P. McCole, P. Ibbotson, D. Compeau "Understanding online customer repurchasing intention and the mediating role of trust: An empirical investigation in two developed countries," European Journal of Information Systems (18), 2009, pp. 205-222.

[22] Y. Zhang, Y. Fang, K.-K. Wei, E. Ramsey, P. McCole, H. Chen "Repurchase intention in B2C e-commerce: A relationship quality perspective," Information \& Management (48:6), 2011, pp. 192-200.

[23] V.Y. Yoon, R.E. Hostler, Z. Guo, T. Guimaraes "Assessing the moderating effect of consumer product knowledge and online shopping experience on using recommendation agents for customer loyalty," Decision Support Systems (55:4), 2013, pp. 883-893.

[24] M. Laroche, M.R. Habibi, M.-O. Richard "To be or not to be in social media: How brand loyalty is affected by social media?," International Journal of Information Management (33:1), 2013, pp. 76-82.

[25] B. Miller "Building e-loyalty of lodging brands: Avoiding brand erosion," Journal of Travel \& Tourism Marketing (17:2-3), 2005, pp. 133-142.

[26] E. Cristobal, C. Flavián, M. Guinalíu "Perceived e-service quality (PeSQ): Measurement validation and effects on consumer satisfaction and web site loyalty," Managing Service Quality (17:3), 2007, pp. 317-340.

[27] B. Jin, J.Y. Park, J. Kim "Cross-cultural examination of the relationships among firm reputation, e-satisfaction, e-trust, and e-loyalty," International Marketing Review (25:3), 2008, pp. 324-337.

[28] M. Carter, R. Wright, J.B. Thatcher, R. Klein "Understanding online customers' ties to merchants: The moderating influence of trust on the relationship between switching costs and e-loyalty," European Journal of Information Systems (23:2014), 2014, pp. 185-204.

[29] C. Pizzutti, D. Fernandes "Effect of recovery efforts on consumer trust and loyalty in e-tail: A contingency model," International Journal of Electronic Commerce (14:4), 2010, pp. 127-160.

[30] D. Cyr, M. Head, A. Ivanov "Perceived interactivity leading to e-loyalty: Development of a model for cognitive-affective user responses," International Journal of Human-Computer Studies (67:10), 2009, pp. 850-869.

[31] D. Gefen, E. Carmel "Is the world really flat? A look at offshoring in an online programming marketplace," MIS Quarterly (32:2), 2008, pp. 367-384.

[32] M. Wetzels, G. Odekerken-Schröder, C. van Oppen "Using PLS path modeling for assessing hierarchical construct models: Guidelines and empirical illustration," MIS Quarterly (33:1), 2009, pp. 177-195.

[33] Y.-S. Wang, S.-C. Wu, H.-H. Lin, Y.-Y. Wang "The relationship of service failure severity, service recovery justice and perceived switching costs with customer loyalty in the context of e-tailing," International Journal of Information Management (31:4), 2011, pp. 350-359.

[34] L.-C. Lu, H.-H. Chang, S.-T. Yu "Online shoppers' perceptions of e-retailers' ethics, cultural orientation, and loyalty: An exploratory study in Taiwan," Internet Research (23:1), 2013, pp. 47-68.

[35] J.M.T. Balmer, S.A. Greyser "Corporate marketing: Integrating corporate identity, corporate branding, corporate communications, corporate image and corporate reputation," European Journal of Marketing (40:7-8), 2006, pp. 730-741.

[36] D. Bickerton "Corporate reputation versus corporate branding: The realist debate," Corporate Communications (5:1), 2000, pp. 42-48. 
[37] P.B. Lowry, A. Vance, G.D. Moody, B. Beckman, A. Read "Explaining and predicting the impact of branding alliances and web site quality on initial consumer trust of e-commerce web sites," Journal of Management Information Systems (24:4), 2008, pp. 199-224.

[38] C. Dennis, A. Newman, R. Michon, J.J. Brakus, L.T. Wright "The mediating effects of perception and emotion: Digital signage in mall atmospherics," Journal of Retailing and Consumer Services (17:3), 2010, pp. $205-215$.

[39] S. Lee, S. Ha, R. Widdows "Consumer responses to high-technology products: Product attributes, cognition, and emotions," Journal of Business Research (64:11), 2011, pp. 1195-1200.

[40] H. Sheng, T. Joqinapelly "Effects of web atmospheric cues on users' emotional responses in e-commerce," AIS Transactions on Human-Computer Interaction (4:1), 2012, pp. 1-24.

[41] L.C. Wang, J. Baker, J.A. Wagner, K. Wakefield "Can a retail web site be social?," Journal of Marketing (71:3), 2007, pp. 143-157.

[42] E. Huang "Online experiences and virtual goods purchase intention," Internet Research (22:3), 2012, pp. 252-274.

[43] R.M. Baron, D.A. Kenny "The moderator-mediator variable distinction in social psychological research: Conceptual, strategic and statistical considerations," Journal of Personality and Social Psychology (51:6), 1986, pp. 1173-1182.

[44] S.A. Eroglu, K.A. Machleit, L.M. Davis "Empirical testing of a model of online store atmospherics and shopper responses," Psychology \& Marketing (20:2), 2003, pp. 139-150.

[45] J.-C. Wang, C.-H. Chang "How online social ties and product-related risks influence purchase intentions: A Facebook experiment," Electronic Commerce Research and Applications (12:5), 2013, pp. 337-346.

[46] S.P. Robbins, M. Coulter Management, Pearson Education, Upper Saddle River, NJ, 2009.

[47] H. Simon "Bounded rationality and organizational learning," Organization Science (2:1), 1991, pp. 125-134.

[48] D. Ariely, I. Simonson "Buying, bidding, playing, or competing? Value assessment and decision dynamics in online auction," Journal of Consumer Psychology (13:1-2), 2003, pp. 113-123.

[49] J. Parke, M. Griffiths "Gambling addiction and the evolution of the 'near miss'," Addiction Research \& Theory (12:5), 2004, pp. 407-411.

[50] P.B. Lowry, J. Gaskin, N. Twyman, B. Hammer, T.L. Roberts "Proposing the hedonic-motivation system adoption model (HMSAM) to increase understanding of adoption of hedonically motivated systems," Journal of the Association for Information Systems (14:11), 2013, pp. 617-671.

[51] J. Wu, X. Lu "Effects of extrinsic and intrinsic motivators on using utilitarian, hedonic, and dual-purposed information systems: A meta-analysis," Journal of the Association for Information Systems (13:3), 2013, pp. 153-191.

[52] H. Van der Heijden "User acceptance of hedonic information systems," MIS Quarterly (28:4), 2004, pp. 695-704.

[53] D. Ribbink, A.C. Van Riel, V. Liljander, S. Streukens "Comfort your online customer: Quality, trust and loyalty on the Internet," Managing Service Quality (14:6), 2004, pp. 446-456. 
[54] C.C. Aggarwal, P.S. Yu "On the network effect in Web 2.0 applications," Electronic Commerce Research and Applications (11:2), 2012, pp. 142-151.

[55] R. Beck, D. Beimborn, T. Weitzel, W. König "Network effects as drivers of individual technology adoption: Analyzing adoption and diffusion of mobile communication services," Information Systems Frontiers (10:4), 2008, pp. 415-429.

[56] M.L. Katz, C. Shapiro "Systems competition and network effects," Journal of Economic Perspectives (8:2), 1994, pp. 93-115.

[57] K. Zhu, K.L. Kraemer, V. Gurbaxani, S. Xu "Migration to open-standard interorganizational systems: Network effects, switching costs, and path dependency," MIS Quarterly (30:Special Issue), 2006, pp. 515-539.

[58] P. Cheng, X. Liu "The impact of network effect on the customer switching intention in mobile telecommunication," Xi'an, China), 2007, pp. 1-5.

[59] M.R. Alesón, M.E. Escuer "The impact of product diversification strategy on the corporate performance of large Spanish firms," Spanish Economic Review (4:2), 2002, pp. 119-137.

[60] S. Tallman, J. Li "Effects of international diversity and product diversity on the performance of multinational firms," Academy of Management Journal (39:1), 1996, pp. 179-196.

[61] G. Qian "Multinationality, product diversification, and profitability of emerging US small- and medium-sized enterprises," Journal of Business Venturing (17:6), 2002, pp. 611-633.

[62] B. Kahn "Variety: From the consumer's perspective " In Product Variety Management, T.-H. Ho and C. S. Tang (Ed.), 10, Springer, New York, NY, 1998, pp. 19-37.

[63] S.P. Anderson, R. Renault "Pricing, product diversity, and search costs: A Bertrand-Chamberlin-Diamond model," RAND Journal of Economics (30:4), 1999, pp. 719-735.

[64] R. Etemad-Sajadi, L. Ghachem "The impact of hedonic and utilitarian value of online avatars on e-service quality," Computers in Human Behavior (52:1), 2015, pp. 81-86.

[65] J.W. Overby, E.J. Lee "The effects of utilitarian and hedonic online shopping value on consumer preference and intentions," Journal of Business Research (59:10-11), 2006, pp. 1160-1166.

[66] F.D. Davis, R.P. Bagozzi, P.R. Warshaw "Extrinsic and intrinsic motivation to use computers in the workplace," Journal of Applied Social Psychology (22:14), 1992, pp. 1111-1132.

[67] W. Na, Y. Son, R. Marshall "Why buy second-best? The behavioral dynamics of market leadership," Journal of Product \& Brand Management (16:1), 2007, pp. 16-22.

[68] S.-J. Hong, K.Y. Tam "Understanding the adoption of multipurpose information appliances: The case of mobile data services," Information Systems Journal (17:2), 2006, pp. 162-179.

[69] F.D. Davis "Perceived usefulness, perceived ease of use, and user acceptance of information technology," MIS Quarterly (13:3), 1989, pp. 318-323.

[70] D. Cyr, K. Hassanein, M. Head, A. Ivanov "The role of social presence in establishing loyalty in e-service environments," Interacting with Computers (19:1), 2007, pp. 43-56.

[71] J.C. Gu, L. Fan, Y.H. Suh, S.C. Lee "Comparing utilitarian and hedonic usefulness to user intention in multipurpose information systems," Cyberpsychology, Behavior, and Social Networking (13:3), 2010, pp. 287-297. 
[72] P. Luarn, H.-H. Lin "A customer loyalty model for e-service context," Journal of Electronic Commerce Research (4:4), 2003, pp. 156-167.

[73] A. Beaudry, A. Pinsonneault "The other side of acceptance: Studying the direct and indirect effects of emotions on information technology use," MIS Quarterly (34:4), 2010, pp. 689-710.

[74] J. Wu, D. Liu "The effects of trust and enjoyment on intention to play online games," Journal of Electronic Commerce Research (8:2), 2007, pp. 128-140.

[75] C.-I. Teng "Customization, immersion satisfaction, and online gamer loyalty," Computers in Human Behavior (26:6), 2010, pp. 1547-1554.

[76] A. Floh, H. Treiblmaier "What keeps the e-banking customer loyal? A multigroup analysis of the moderating role of consumer characteristics on e-loyalty in the financial service industry," Journal of Electronic Commerce Research (7:2), 2006, pp. 97-110.

[77] V. Venkatesh "Determinants of perceived ease of use: Integrating control, intrinsic motivation, and emotion into the technology acceptance model," Information Systems Research (11:4), 2000, pp. 342-365.

[78] A.H. Maslow "A theory of human motivation," Psychological Review (50:4), 1943, pp. 370-396.

[79] P.B. Lowry, J. Gaskin, G.D. Moody "Proposing the multimotive information systems continuance model (MISC) to better explain end-user system evaluations and continuance intentions," Journal of the Association for Information Systems (16:7), 2015, pp. 515-579.

[80] X. Cui, V.S. Lai "Bidding strategies in online single-unit auctions: Their impact and satisfaction," Information \& Management (50:6), 2013, pp. 314-321.

[81] A. Prasad, R. Venkatesh, V. Mahajan "Optimal bundling of technological products with network externality," Management Science (56:12), 2010, pp. 2224-2236.

[82] S. Lee, J.S. Brown, S. Lee "A cross-country analysis of fixed broadband deployment: Examination of adoption factors and network effect," Journalism \& Mass Communication Quarterly (88:3), 2011, pp. 580-596.

[83] H.K. Cheng, Q.C. Tang "Free trial or no free trial: Optimal software product design with network effects," European Journal of Operational Research (205:2), 2010, pp. 437-447.

[84] J. Zhang, A. Seidmann "Perpetual versus subscription licensing under quality uncertainty and network externality effects," Journal of Management Information Systems (27:1), 2010, pp. 39-68.

[85] A. Dickinger, M. Arami, D. Meyer "The role of perceived enjoyment and social norm in the adoption of technology with network externalities," European Journal of Information Systems (17:1), 2008, pp. 4-11.

[86] S. Rafaeli, A. Noy "Social Presence: Influence on bidders in Internet auctions," Electronic Markets (15:2), 2005, pp. 158-175.

[87] H.-P. Lu, K.-Y. Lin "Factors influencing online auction sellers' intention to pay: An empirical study integrating network externalities with perceived value," Journal of Electronic Commerce Research (13:3), 2012, pp. 238-254.

[88] M. Lin, N.R. Prabhala, S. Viswanathan "Judging borrowers by the company they keep: Friendship networks and information asymmetry in online peer-to-peer lending," Management Science (59:1), 2013, pp. 17-35.

[89] E. Brynjolfsson, Y.J. Hu, M.D. Smith "Long tails vs. superstars: The effect of information technology on 
product variety and sales concentration patterns," Information Systems Research (21:4), 2010, pp. 736-747.

[90] K. Wang, E.T.G. Wang, C.-F. Tai "A study of online auction sites in Taiwan: Product, auction rule, and trading type," International Journal of Information Management (22:2), 2002, pp. 127-142.

[91] E. Brynjolfsson, Y.J. Hu, M.D. Smith "Consumer surplus in the digital economy: Estimating the value of increased product variety at online booksellers," Management Science (49:11), 2003, pp. 1580-1596.

[92] H.C.M. Van Trijp, W.D. Hoyer, J.J. Inman "Why switch? Product category-level explanations for true variety-seeking behavior," Journal of Marketing Research (33:3), 1996, pp. 281-296.

[93] K.M. Sheldon, J.K. Boehm, S. Lyubomirsky "Variety is the spice of happiness: The hedonic adaptation prevention (HAP) model," In Oxford Handbook of Happiness, S. David, I. Boniwell and A. C. Ayers (Ed.), Oxford University Press, Oxford, UK, 2013, pp. 901-914.

[94] K.L. Wakefield, J. Baker "Excitement at the mall: Determinants and effects on shopping response," Journal of Retailing (74:4), 1998, pp. 515-539.

[95] C.-C. Shen, J.-S. Chiou "The impact of perceived ease of use on Internet service adoption: The moderating effects of temporal distance and perceived risk," Computers in Human Behavior (26:1), 2010, pp. 42-50.

[96] P.A. Pavlou, D. Gefen "Building effective online marketplaces with institution-based trust," Information Systems Research (15:1), 2004, pp. 37-59.

[97] S. Chakravarty, K. Dogan, N. Tomlinson "A hedonic study of network effects in the market for word processing software," Decision Support Systems (41:4), 2006, pp. 747-763.

[98] M.L. Katz, C. Shapiro "Network externalities, competition, and compatibility," American Economic Review (75:3), 1985, pp. 424-440.

[99] G. Saloner, A. Shepard "Adoption of technologies with network effects: An empirical examination of the adoption of automated teller machines," Rand Journal Autumn (26:3), 1995, pp. 479-501.

[100] S.Y. Lam, V. Shankar, M.K. Erramilli, B. Murthy "Customer value, satisfaction, loyalty, and switching costs: An illustration from a business-to-business service context," Academy of Marketing Science (32:3), 2004, pp. 293-311.

[101] D.W. Straub "Validating instruments in MIS research," MIS Quarterly (13:2), 1989, pp. 147-169.

[102] P.B. Lowry, J. Cao, A. Everard "Privacy concerns versus desire for interpersonal awareness in driving the use of self-disclosure technologies: The case of instant messaging in two cultures," Journal of Management Information Systems (27:4), 2011, pp. 163-200.

[103] J.C. Nunnally, I.H. Bernstein Psychometric Theory, McGraw-Hill, New York, NY, 1994.

[104] J.M. Stanton, S.G. Rogelberg "Using Internet/intranet web pages to collect organizational research data," Organizational Research Methods (4:3), 2001, pp. 167-176.

[105] D.B. McFarlin, P.D. Sweeney "Distributive and procedural justice as predictors of satisfaction with personal and organizational outcomes," Academy of Management Journal (35:3), 1992, pp. 626-637.

[106] D. Gefen, D.W. Straub, E.E. Rigdon "An update and extension to SEM guidelines for administrative and social science research," MIS Quarterly (35:2), 2011, pp. iii-xiv. 
[107] L.-t. Hu, P.M. Bentler "Cutoff criteria for fit indexes in covariance structure analysis: Conventional criteria versus new alternatives," Structural Equation Modeling (6:1), 1999, pp. 1-55.

[108] C. Fornell, D.F. Larcker "Evaluating structural equation models with unobservable variables and measurement error," Journal of Marketing Research (18:1), 1981, pp. 29-50.

[109] X. Zhao, B. Huo, B.B. Flynnc, J.H.Y. Yeung "The impact of power and relationship commitment on the integration between manufacturers and customers in a supply chain," Journal of Operations Management (26:3), 2008, pp. 368-388.

[110] P.B. Lowry, J. Gaskin "Partial least squares (PLS) structural equation modeling (SEM) for building and testing behavioral causal theory: When to choose it and how to use it," IEEE Transactions on Professional Communication (57:2), 2014, pp. 123-146.

[111] B.J. Babin, W.R. Darden, M. Griffin "Work and/or fun: Measuring hedonic and utilitarian shopping value," Journal of Consumer Research (20:4), 1994, pp. 644-656.

[112] S. Vodanovich, D. Sundaram, M. Myers "Digital natives and ubiquitous information systems," Information Systems Research (21:4), 2010, pp. 711-723.

[113] R.E. Anderson, S.S. Srinivasan "E-satisfaction and e-loyalty: A contingency framework," Psychology \& Marketing (20:2), 2003, pp. 123-138.

[114] C. Posey, P.B. Lowry, T.L. Roberts, S. Ellis "Proposing the online community self-disclosure model: The case of working professionals in France and the UK who use online communities," European Journal of Information Systems (19:2), 2010, pp. 181-195.

[115] P.B. Lowry, D. Zhang, L. Zhou, X. Fu "Effects of culture, social presence, and group composition on trust in technology-supported decision-making groups," Information Systems Journal (20:3), 2010, pp. 297-315. 
APPENDIX A. SUMMARY OF RECENT INVESTIGATIONS IN S-O-R

\begin{tabular}{|c|c|c|c|c|c|c|c|c|}
\hline Authors & $\begin{array}{l}\text { Research Context } \\
\text { \& Methods }\end{array}$ & $\begin{array}{l}\text { Stimulus } \\
\text { Factors }\end{array}$ & Categories & $\begin{array}{l}\text { Organism } \\
\text { Factors }\end{array}$ & $\begin{array}{l}\text { Response } \\
\text { Factors }\end{array}$ & $\begin{array}{l}\text { Moderator } \\
\text { Factors }\end{array}$ & $\begin{array}{l}\text { Interaction between } \\
\text { Organism reactions }\end{array}$ & $\begin{array}{l}\text { Mediating Effect of } \\
\text { Organism }\end{array}$ \\
\hline $\begin{array}{l}\text { Eroglu et } \\
\text { al. [44] }\end{array}$ & $\begin{array}{l}\text { online shopping; } \\
\text { experiment }\end{array}$ & $\begin{array}{l}\text { task-relevant } \\
\text { cues }\end{array}$ & technological & $\begin{array}{l}\text { pleasure, } \\
\text { arousal, } \\
\text { attitude }\end{array}$ & $\begin{array}{l}\text { satisfaction, } \\
\text { approach/ } \\
\text { avoidance }\end{array}$ & $\begin{array}{l}\text { involvement, } \\
\text { atmospheric } \\
\text { responsiveness }\end{array}$ & pleasure $\rightarrow$ attitude & $\begin{array}{l}\text { full mediation of } \\
\text { organism factors }\end{array}$ \\
\hline $\begin{array}{l}\text { Mummalan } \\
\text { eni [11] }\end{array}$ & $\begin{array}{l}\text { online shopping; } \\
\text { survey }\end{array}$ & $\begin{array}{l}\text { website design, } \\
\text { ambience }\end{array}$ & $\begin{array}{l}\text { technological } \\
\text { and } \\
\text { ambience-relat } \\
\text { ed }\end{array}$ & $\begin{array}{l}\text { arousal, } \\
\text { pleasure }\end{array}$ & $\begin{array}{l}\text { satisfaction, } \\
\text { \# of items } \\
\text { purchased, } \\
\text { loyalty }\end{array}$ & N/A & N/A & $\begin{array}{l}\text { full mediation except } \\
\text { partial mediation } \\
\text { between } \\
\text { ambience/loyalty }\end{array}$ \\
\hline $\begin{array}{l}\text { Wang et al. } \\
\text { [41] }\end{array}$ & $\begin{array}{l}\text { online shopping; } \\
\text { experiment }\end{array}$ & socialness & social & $\begin{array}{l}\text { arousal, flow, } \\
\text { pleasure, } \\
\text { values }\end{array}$ & $\begin{array}{l}\text { patronage } \\
\text { intention }\end{array}$ & $\begin{array}{l}\text { involvement, } \\
\text { demographics } \\
\text { attributes }\end{array}$ & $\begin{array}{l}\text { They interact with } \\
\text { each other. }\end{array}$ & N/A \\
\hline $\begin{array}{l}\text { Parboteeah } \\
\text { et al. [7] }\end{array}$ & $\begin{array}{l}\text { online shopping; } \\
\text { experiment }\end{array}$ & $\begin{array}{l}\text { task-relevant/ } \\
\text { mood-relevant } \\
\text { cues }\end{array}$ & technological & $\begin{array}{l}\text { perceived } \\
\text { usefulness/ } \\
\text { enjoyment }\end{array}$ & $\begin{array}{l}\text { urge to buy } \\
\text { impulsively }\end{array}$ & N/A & $\begin{array}{l}\text { usefulness } \rightarrow \text { enjoyme } \\
\text { nt }\end{array}$ & $\begin{array}{l}\text { full mediation of } \\
\text { perceived enjoyment }\end{array}$ \\
\hline $\begin{array}{l}\text { Jiang et al. } \\
\text { [6] }\end{array}$ & $\begin{array}{l}\text { online shopping; } \\
\text { experiment }\end{array}$ & active control & technological & $\begin{array}{l}\text { cognitive/ } \\
\text { affective } \\
\text { involvement }\end{array}$ & $\begin{array}{l}\text { purchase } \\
\text { intention }\end{array}$ & N/A & N/A & full mediation \\
\hline $\begin{array}{l}\text { Koo and } \mathrm{Ju} \\
{[8]}\end{array}$ & $\begin{array}{l}\text { online shopping; } \\
\text { survey }\end{array}$ & $\begin{array}{l}\text { graphics, } \\
\text { colours, links }\end{array}$ & technological & $\begin{array}{l}\text { pleasure, } \\
\text { arousal }\end{array}$ & use intention & $\begin{array}{l}\text { perceptual } \\
\text { curiosity }\end{array}$ & N/A & N/A \\
\hline $\begin{array}{l}\text { Lee et al. } \\
\text { [39] }\end{array}$ & $\begin{array}{l}\text { not specified; } \\
\text { survey }\end{array}$ & $\begin{array}{l}\text { innovativeness } \\
\text { of technology, } \\
\text { visual appeal, } \\
\text { prototypicality, } \\
\text { self-expression }\end{array}$ & technological & $\begin{array}{l}\text { attitude, } \\
\text { pleasure, } \\
\text { arousal }\end{array}$ & $\begin{array}{l}\text { approach/ } \\
\text { avoidance } \\
\text { behaviour }\end{array}$ & N/A & arousal $\rightarrow$ pleasure & N/A \\
\hline
\end{tabular}




\begin{tabular}{|c|c|c|c|c|c|c|c|c|}
\hline Huang [42] & $\begin{array}{l}\text { online shopping; } \\
\text { survey }\end{array}$ & $\begin{array}{l}\text { active control, } \\
\text { reciprocal com., } \\
\text { social identity }\end{array}$ & $\begin{array}{l}\text { technological } \\
\text { and social }\end{array}$ & $\begin{array}{l}\text { cognitive/ } \\
\text { affective } \\
\text { involvement, } \\
\text { flow }\end{array}$ & $\begin{array}{l}\text { purchase } \\
\text { intention }\end{array}$ & N/A & involvement $\rightarrow$ flow & N/A \\
\hline $\begin{array}{l}\text { Sheng and } \\
\text { Joqinapelly } \\
\text { [40] }\end{array}$ & $\begin{array}{l}\text { online shopping; } \\
\text { experiment \& } \\
\text { survey }\end{array}$ & $\begin{array}{l}\text { vividness, } \\
\text { interactivity }\end{array}$ & technological & $\begin{array}{l}\text { arousal } \\
\text { valence }\end{array}$ & $\begin{array}{l}\text { purchase } \\
\text { intention }\end{array}$ & N/A & N/A & N/A \\
\hline $\begin{array}{l}\text { Song et al. } \\
\text { [9] }\end{array}$ & $\begin{array}{l}\text { online promotion; } \\
\text { experiment }\end{array}$ & $\begin{array}{l}\text { product } \\
\text { integration level }\end{array}$ & $\begin{array}{l}\text { product-relate } \\
\text { d }\end{array}$ & $\begin{array}{l}\text { perceived tie, } \\
\text { perceived fit }\end{array}$ & $\begin{array}{l}\text { attitude, } \\
\text { intention }\end{array}$ & user expertise & N/A & $\begin{array}{l}\text { no clear report of full } \\
\text { or partial mediating } \\
\text { effect }\end{array}$ \\
\hline $\begin{array}{l}\text { Wang and } \\
\text { Chang [45] }\end{array}$ & $\begin{array}{l}\text { online shopping; } \\
\text { experiment }\end{array}$ & tie strength & social & $\begin{array}{l}\text { perceived } \\
\text { diagnosticity }\end{array}$ & $\begin{array}{l}\text { purchase } \\
\text { intention }\end{array}$ & $\begin{array}{l}\text { product-related } \\
\text { risk }\end{array}$ & N/A & full mediation \\
\hline
\end{tabular}




\section{APPENDIX B. MEASUREMENT DETAILS FOR THIS RESEARCH}

\begin{tabular}{|c|c|}
\hline Construct (Source) & Measurement Items \\
\hline $\begin{array}{l}\text { Bidding tool } \\
\text { effectiveness; } \\
\text { adapted from } \\
\text { Pavlou and Gefen } \\
\text { [96] }\end{array}$ & $\begin{array}{l}\text { 1. The bidding tool is effective. } \\
\text { 2. The bidding tool is reliable. } \\
\text { 3. The bidding tool can facilitate better service for me. } \\
\text { 4. The bidding tool can help me bid as I want. }\end{array}$ \\
\hline $\begin{array}{l}\text { WTI effectiveness; } \\
\text { adapted from } \\
\text { Pavlou and Gefen } \\
\text { [96] }\end{array}$ & $\begin{array}{l}\text { 1. The "watch the item" function is effective. } \\
\text { 2. The "watch the item" function is reliable. } \\
\text { 3. The "watch the item" function can facilitate better service for me. } \\
\text { 4. The "watch the item" function can help me bid as I want. }\end{array}$ \\
\hline $\begin{array}{l}\text { Network effect; } \\
\text { developed from } \\
\text { Zhu et al. [57]; } \\
\text { Chakravarty et al. } \\
\text { [97]; and Katz and } \\
\text { Shapiro [98] }\end{array}$ & $\begin{array}{l}\text { 1. The growth of the auction website brings me more utility. } \\
\text { 2. The growth of the auction website brings me more benefit. } \\
\text { 3. The growth of the auction website brings me more value. } \\
\text { 4. The growth of the auction website brings me more convenience. }\end{array}$ \\
\hline $\begin{array}{l}\text { Product diversity; } \\
\text { Developed from } \\
\text { Brynjolfsson et al. } \\
\text { [89]; and } \\
\text { Brynjolfsson et al. } \\
\text { [91] }\end{array}$ & $\begin{array}{l}\text { 1. The auction website provides various products. } \\
\text { 2. There is a great variety of products on the auction website. } \\
\text { 3. The auction website provides many good product choices. } \\
\text { 4. This auction website has better stocks than other auction websites. }\end{array}$ \\
\hline $\begin{array}{l}\text { Perceived bidding } \\
\text { enjoyment; } \\
\text { adapted from } \mathrm{Na} \text { et } \\
\text { al. [67] }\end{array}$ & $\begin{array}{l}\text { 1. This auction website makes me feel good. } \\
\text { 2. When I think of this auction website, I have pleasant memories. } \\
\text { 3. This auction website gives me sensory pleasure. }\end{array}$ \\
\hline $\begin{array}{l}\text { Perceived bidding } \\
\text { utility; adapted } \\
\text { from Na et al. [67] }\end{array}$ & $\begin{array}{l}\text { 1. This auction website has good performance. } \\
\text { 2. The overall quality of this auction website is good. } \\
\text { 3. This auction website is useful. } \\
\text { 4. This auction website is helpful to me. } \\
\text { 5. This auction website has a credible image. }\end{array}$ \\
\hline $\begin{array}{l}\text { Bidder loyalty; } \\
\text { adapted from Cyr et } \\
\text { al. [70]; and Lam et } \\
\text { al. [100] }\end{array}$ & $\begin{array}{l}\text { 1. I will reuse this auction website frequently in the future. } \\
\text { 2. I will reuse this auction website regularly in the future. } \\
\text { 3. I will recommend this auction website to others. }\end{array}$ \\
\hline
\end{tabular}


APPENDIX C. FACTOR LOADING MATRIX

\begin{tabular}{|c|c|c|c|c|c|c|c|}
\hline & $\begin{array}{l}\text { Product } \\
\text { diversity } \\
\text { (PD) }\end{array}$ & $\begin{array}{l}\text { Bidding tool } \\
\text { effectiveness } \\
\text { (BTE) }\end{array}$ & $\begin{array}{l}\text { Perceived } \\
\text { bidding utility } \\
\text { (PBU) }\end{array}$ & $\begin{array}{l}\text { Network } \\
\text { effect } \\
(\mathrm{NE})\end{array}$ & $\begin{array}{l}\text { WTI } \\
\text { effectiveness } \\
\text { (WTIE) }\end{array}$ & $\begin{array}{l}\text { Bidder } \\
\text { loyalty } \\
(\mathrm{BL})\end{array}$ & $\begin{array}{l}\text { Perceived } \\
\text { bidding } \\
\text { enjoyment } \\
(\mathrm{PBE})\end{array}$ \\
\hline BTE1 & 0.007 & 0.891 & 0.123 & 0.071 & 0.054 & 0.076 & 0.125 \\
\hline BTE2 & 0.027 & 0.892 & 0.124 & 0.104 & 0.068 & 0.054 & 0.082 \\
\hline BTE3 & 0.046 & 0.906 & 0.127 & 0.089 & 0.081 & 0.041 & 0.149 \\
\hline BTE4 & 0.030 & 0.836 & 0.088 & 0.125 & 0.151 & 0.122 & 0.011 \\
\hline WTIE1 & 0.027 & 0.039 & 0.168 & 0.045 & 0.835 & 0.053 & 0.093 \\
\hline WTIE2 & 0.024 & 0.149 & 0.193 & 0.174 & 0.803 & 0.110 & 0.121 \\
\hline WTIE3 & 0.068 & 0.113 & 0.168 & 0.153 & 0.846 & 0.127 & 0.170 \\
\hline WTIE4 & 0.043 & 0.069 & 0.083 & 0.167 & 0.731 & 0.132 & 0.072 \\
\hline NE1 & 0.168 & 0.158 & 0.294 & 0.774 & 0.174 & 0.138 & 0.134 \\
\hline NE2 & 0.106 & 0.082 & 0.192 & 0.853 & 0.168 & 0.166 & 0.106 \\
\hline NE3 & 0.143 & 0.116 & 0.163 & 0.823 & 0.136 & 0.207 & 0.109 \\
\hline NE4 & 0.101 & 0.111 & 0.217 & 0.770 & 0.142 & 0.112 & 0.205 \\
\hline PD1 & 0.907 & 0.030 & 0.096 & 0.118 & 0.044 & 0.084 & 0.088 \\
\hline PD2 & 0.929 & 0.016 & 0.058 & 0.104 & 0.041 & 0.129 & 0.042 \\
\hline PD3 & 0.874 & 0.017 & 0.083 & 0.094 & 0.036 & 0.117 & 0.076 \\
\hline PD4 & 0.845 & 0.043 & 0.069 & 0.106 & 0.038 & 0.088 & 0.132 \\
\hline PBE1 & 0.186 & 0.190 & 0.369 & 0.174 & 0.210 & 0.159 & 0.651 \\
\hline PBE2 & 0.107 & 0.127 & 0.208 & 0.196 & 0.174 & 0.178 & 0.817 \\
\hline PBE3 & 0.150 & 0.148 & 0.204 & 0.193 & 0.175 & 0.267 & 0.770 \\
\hline PBU1 & 0.064 & 0.133 & 0.835 & 0.187 & 0.237 & 0.007 & 0.069 \\
\hline PBU2 & 0.056 & 0.162 & 0.850 & 0.199 & 0.204 & 0.063 & 0.135 \\
\hline PBU3 & 0.120 & 0.100 & 0.607 & 0.298 & 0.151 & 0.347 & 0.327 \\
\hline PBU4 & 0.157 & 0.106 & 0.591 & 0.249 & 0.132 & 0.414 & 0.268 \\
\hline PBU5 & 0.131 & 0.183 & 0.733 & 0.269 & 0.146 & 0.176 & 0.301 \\
\hline BL1 & 0.080 & 0.096 & 0.036 & 0.133 & 0.033 & 0.692 & 0.131 \\
\hline BL2 & 0.188 & 0.055 & 0.199 & 0.165 & 0.188 & 0.755 & 0.206 \\
\hline BL3 & 0.148 & 0.100 & 0.148 & 0.179 & 0.197 & 0.778 & 0.104 \\
\hline
\end{tabular}

